\title{
The Impact of Acquisitions Deals Announcement According to Financing Decisions on Value of Listed Acquiring Companies at Egyptian Stock Exchange
}

\author{
Ahmed A.Elhakeem ${ }^{1} \&$ Khairy Elgiziry ${ }^{2}$ \\ ${ }^{1}$ Senior Partner of Ahmed Abd Elhakeem Company For Accounting and Auditing, Cairo, Egypt \\ ${ }^{2}$ Professor of Finance in Cairo University, Egypt \\ Correspondence: Ahmed A.Elhakeem, Senior Partner of Ahmed Abd Elhakeem Company For Accounting and \\ Auditing, Cairo, Egypt
}

Received: September 27, 2016

Accepted: October 16, 2016

Online Published: October 18, 2016

doi:10.5430/afr.v5n4p115

URL: http://dx.doi.org/10.5430/afr.v5n4p115

\begin{abstract}
This study investigated the impact of short and long term acquisition deals announcement according to financing decisions on value of listed acquiring companies at Egyptian Stock Exchange. Short-term and long-term study methodology was applied to analyze average abnormal returns and cumulative average abnormal returns for a sample of acquiring companies held in the Egyptian stock exchange. Long-term event study methodology is applied according to annually buy-hold abnormal return method (ABHAR). Average abnormal returns and cumulative average abnormal returns were calculated to evaluate the acquirer's return for a sample of 31 acquiring companies listed and traded at Egyptian stock exchange during the period 2005-2014. The Sample is selected from 212 acquiring companies which completed the acquisition during the period. Paired T-test, Mann Whitney and ETA measurements were used to determine whether there was significant difference between the means in pre/post events. The results indicate that acquisitions did not generate cumulative average abnormal returns (CAAR) during the event window of 40 days $(-20,+20)$ for the entire sample, but the acquisitions generated $26.67 \%$ (statistically significant) cumulative average abnormal returns during long-term event period. The Positive abnormal returns were not observed in the case of acquisitions financed with cash, stock or mix during the 40 days event window (short-term), but on long-term where the acquisitions were financed with cash and stock positive abnormal returns are generated and were not observed in the case of acquisitions financed with mix method.
\end{abstract}

Keywords: Acquisition, Short-term event study, Long-term event study, Acquisition financing strategy, Annually buy-hold abnormal return method

\section{Introduction}

Recently, acquisitions are getting to be more commonly accepted by the Egyptian businesses as a critical business strategy supported by the evidence that 212 acquisition deals by Egyptian corporations took place within the period 2005-2011. Accessing the market through an established brand, inter-alia, reducing competition, increasing market share, acquiring competence, reducing tax liabilities, and adjusting accumulated losses of one entity against the profits of another entity may be considered as some justifications assigned to adopting this strategy (Melati et al, 2014). Acquisitions are classified as assets and shares acquisitions. This study heavily considered the acquisitions of shares which is divided into three categories: (i) complete takeover (i.e., 100\% of target's issued shares), (ii) majority acquisition (iii) significant minority acquisition (Dibyendu \& Pankaj, 2009). This study not only attempts to examine the impact of acquisition announcements on Egyptian acquiring firms shareholders' wealth termism, but also defines that impact according to method of funding (i.e., cash, exchange of shares, or mixed).

For better exposition, the paper is organized into six sections including this section. Section 2 presents the previous empirical research work related to acquisitions announcement events and hypotheses development. Data collection and sample selection related issues have been delineated in section 3. Section 4 explains the objectives, hypotheses of the study and methodology used. Empirical results and analysis are discussed in section 5 while concluded observations, limitations and future research directions are showed in section 6 . 


\section{Literature Review and Hypotheses Development}

There are two main approaches in the existing acquisition literature: the stock market-based approach and the accounting-based approach. Stock market-based approach studies are contingent on determining the financial gains and losses resulting from acquisitions. On the other hand, the accounting-based approach (i.e., based on accounting data analysis) uses accounting ratios from financial statements and applies modification mechanisms in operating performance following acquisitions. In this section, we provided a survey of literature for both developed and emerging market that use either the stock market-based approach or the accounting-based approach.

Anson Wong \& Kui Yin Cheung (2009) Employed an event study methodology (-50.+50) to examine a sample of 658 deals listed in emerging market in Hong Kong, China, Taiwan, Singapore, South Korea, and Japan for the period 2000-2007. They found a positive and significant abnormal return for shareholders of acquiring companies.

Jianyu Ma et al. (2009) examined stock market reactions toward acquisition announcement events. They used the event study methodology for 1477 acquisition deals in 10 emerging market such as Hong Kong, Indonesia, Malaysia, Philippines, Singapore, South Korea, Taiwan, Thailand, China, and India and used T-test statistical analysis. Their results showed that -on average- there is a positive and significant increase in the value of acquiring companies.

Darius Saikevicius (2013) examined whether value creation differs in domestic and cross-border transactions around the day of acquisition announcement. Their study used a sample of 747 domestic and cross-border acquisitions in European stock exchange occurred over the period 2004-2011. Event study methodology was applied according to market model to calculate abnormal returns around event day $(-5,+5)$. They found that the value creation by cross-border acquisitions is more than those of domestic acquisitions.

Mohammad Naserbakh (2013) analyzed short-term shareholders wealth effects of American banking sector acquisitions. Event study methodology has been used to assess the impact on acquiring banks' stock prices. His results documented positive and significant increase in the value of the shareholders of bidder banks.

The Efficient Market Hypothesis states that asset prices fully reflect all available information. A direct implication is that it is impossible to "beat the market" consistently on a risk-adjusted basis since market prices should only react to new information or changes in discount rates. Thus, stocks will always trade at their fair value, making it impossible for investors to either purchase undervalued stocks or sell stocks for inflated prices as argued by Eugene Fama. That is why; Nick Gersdorff \& Frank Bacon (2010) examined the American market's efficiency by announcement of acquisition deals. The standard risk adjusted event study methodology was employed on 20 acquiring companies in American market listed in NASDAQ or NYSE based on market capitalizations (S\&P 500 Index) . They found positive returns of post-event describing the American market as a semi-strong efficient market.

Domingues et al (2012) investigated the relationship between the announcement of acquisition and market efficiency in Argentina, Brazil, and Chile. He tried to determine whether the announcement of acquisition is perceived as unexpected good news by the market and if the market reacts positively to such events. Event study methodology was employed for period of 5 days pre/post events, and T-test was used for statistical analysis. Results showed significant abnormal returns in the event window particularly within the 5 days following the event in Argentina and Chile and the absence of such in Brazil suggesting a more efficient market in Brazil.

Rajani Ramdas \& Jyothi Kumar (2014) investigated the impact of corporate restructuring on value creation for the shareholders. They used annual reports of the company's' websites as a measure of shareholders' value for the period 2000-2013. They used financial tools such as Economic value added (EVA), Market value added (MVA), and Enterprise value to measure value creation and descriptive statistics, correlation, and regression to analyze results statistically. Econometric analysis and GARCH model were also used. Results showed that the announcements of acquisition deals did not create value at short-term as not all acquisitions basically aim to maximize the shareholders' wealth but controlling may also be a depending driver for acquisition announcement.

Ajai S. Gaur et al. (2014) examined positive reactions of stock market as to acquisition announcements in China. They used longitudinal sample of the Chinese domestic and cross-border acquisitions from 1993-2008. Data was collected from SDC Platinum database and event study methodology was used for measuring the stock market reaction to acquisitions announcement with a five-day's event window to look at prices two days before and two days after the announcement date. They found that the Chinese acquiring companies earned positive abnormal returns which contrasted the findings in developed economies that acquiring firms generally experience negative or no abnormal returns from acquisition announcement deals.

Defining Pakistan as an emerging markets, and according to that the main problem in event study which is market valuations around the announcement data that explains not only market efficiency but also undervaluation or 
overvaluation of acquiring companies' stocks, Muhammad Amir et al (2014) tested the impact of acquisitions announcement on shareholders' wealth pre-event and post-event. They applied event study methodology and T-test on the event period $(-5,+5)$ on a sample of acquiring companies listed and traded during the period 2006-2010 and found no abnormal returns.

Neelam Rani, Surendra S. Yaday \& P. K. Jain (2014) attempted to compare the impact of domestic acquisitions and cross-border acquisitions in India. The sample consisted of the announcements of acquisitions by Indian companies listed in Bombay stock exchange for the period 2003-2008 and data was collected from Thomson SDC Platinum Mergers and acquisitions database including 268 domestic and 255 target firms across border. A segregated analysis has been conducted to measure the impact of stake/control acquired and an event study methodology has been conducted to analyze the share price performance of Indian acquirers in short-term. Findings revealed that cross-border as well as domestic acquisitions enhance shareholders' wealth of the acquirer company on the announcement and that cross-border acquisitions generate higher returns than domestic acquisitions. Nonetheless, the segregated analysis showed that the shareholders of acquiring firms of complete cross-border acquisitions earn higher abnormal returns (5\%) - though statistically insignificant- for partial/majority control domestic acquisitions.

One viewpoint stated that acquisition offer an appropriate framework to study the interaction between investment and financing decisions, Sanjay Sehgal et al (2012) examined if acquisition announcements and methods of financing these deals affect stock returns. They collected data for 214 acquisitions deals listed in stock exchange of Brazil, Russia, India, China, South Korea, and South Africa. Event study methodology and T-test statistical were used on the period $(-50,+50)$. Results indicated that while stock-financed acquisitions are value creating, cash-financed acquisitions seem to be value-destroying in the short run.

Houssam Bouzgarrou (2014) studied the impact of cash-financed acquisitions by internally generated free cash flows on shareholders' wealth of acquiring companies. He selected 265 acquisitions deals listed in Tunisia stock exchange which financed the acquisitions deals by internally generated free cash flows. He used Event study methodology and $\mathrm{T}$-test statistical analysis and found that there is a negative relationship between internally generated free cash flows and abnormal returns of acquisitions announcement.

Thomas J.Chemmanur et al. (2009) presented a very important study for testing the choice of the medium of exchange in acquisitions when both acquirers and targets possess private information about their own intrinsic values. Their dependent variable is the medium of exchange and the independent variables are the value of both the acquirer and the target. They used two models: the residual income model (RIM) and OHLSON model (OHL). The Sample was selected according to some criteria: (1) the acquiring and the target companies being listed and traded in American stock exchange, and (2) the acquiring companies own at least $50 \%$ from the equity of the target before the acquisition and $100 \%$ after the acquisition. Accordingly, the sample included 817 acquisitions deals: $43 \%$ cash acquisition $47 \%$ stock acquisition $10 \%$ mix acquisition and they used CRSP to obtain data regarding accounting prices of stocks and returns. They found that private information held by both acquirers and targets together determine the medium of exchange.

There are several studies based on accounting indications from audited published financial statements when evaluating performance of stock price in long term. E. Akben Selcuk \& A. Altiok Yilmaz (2011) investigated the impact of acquisition deals on the performance of acquirer Turkish companies. A total of 62 companies involved in acquisitions deals between 2003 and 2007 were included in the sample. They obtained the data of acquiring companies from Turkish stock exchange and the data of post-acquisition from published financial statement. They used event study methodology and T-test statistical analysis on the event period and accounting approach based on three indicators: return on assets, return on equity and return on sales, and applied the change model. Event study analysis showed that the abnormal returns are negative and statistically different from zero for 10-day and 7-day event windows. Also CAR $(-5,-1)$ and CAR $(-3,-1)$ values are significantly negative, indicating pre-event leakage. When accounting data was used, parametric t-test showed that post-acquisition ROA and ROS values are significantly lower than pre-acquisition values.

Mergers and acquisitions (M\&A) in the corporate world are achieving increasing importance and attention especially with the advent of intense globalization. Onaolapo Adekunle \& Ajala Oladayo (2012) investigated the impact of Acquisition deals on the performance of commercial banks in Nigeria based on a model consists of (1) dependent variables : capital structure, credit risk, liquidity risk, asset profile, and operating efficiency, and (2) independent variables : return on assets, return on equity, and net profit margin. The research analysis used published audited accounts of ten out of twenty-four banks that emerged from the consolidation exercise and data from the Central Banks of Nigeria. The data is analyzed by Pearson correlation and Multiple Regression analysis. Results showed that 
the acquisitions led to improvement of banks performance.

Also, Anderibom Asauten \& Obute Christopher (2015) examined the impact of acquisitions on performance of commercial banks. They applied their study on United Bank for Africa by using financial indicators based on audited and published financial statement for the period 2000-2010. The financial indicators consist of: capital, assets, management, earning, and liquidity. They used Pair Sample T-test and found a positive relationship between the acquisitions and financial performance of the bank.

Concerning the manufacturing sector, Ramachandran Azhagaiah \& Thangavelu Sathishkuma (2014) aimed to examine the impact of acquisitions on post-operating performance for acquiring manufacturing companies in India. The sample consisted of 179 acquisitions deals during the period 2006-2007. They used data collected from the capital market database called Centre for Monitoring Indian Economy Private Limited (Prowess cmie). Their study consisted of two sub-periods: pre-acquisition period from 2002-2006 and post-acquisition period from 2008-2012. The study's model dependent variable is the return on equity and the independent variables are gross earnings, liquidity, financial leverage, and cost of utilization, turnover, and operating leverage. Results showed that the acquisitions deals led to improvement of long-run operating performance after the acquisitions.

This paper differs from previous literature studying acquisitions in two important aspects. First, the study included the impact of acquisition announcement event on Egyptian acquiring firms' shareholders wealth in short-term and long-term in general, and second, the impact of acquisitions on Egyptian acquiring firms' shareholders wealth in short-term and long-term according to method of finance (cash, shares, and mixed). Hence, the main question of the research is "what is the impact of acquisitions announcement event on Egyptian acquiring firms' shareholders wealth in short-term and long-term according to method of finance?"

According to the literature review, we have constructed hypotheses of the research as follow:

- The results of literature review are mixed (positive - negative - positive and negative), in addition of market reaction to acquisition announcement in developed countries may be quite different and distinct from that of in case of developed countries. No studies in literature review examined the impact of acquisition announcement event on acquiring firms' shareholders wealth in long-term. Accordingly, we have constructed hypothesis No1 and No2 as follow:

H1: There is no significant impact of the acquisitions deals announcement on realized return of acquiring companies' shares surrounding date of acquisitions announcement.

H2: There is no significant impact of acquisitions deals announcement on realized return of acquiring companies' shares on long-term.

- $\quad$ There are several studies in literature review based on medium of exchange in acquisitions on short - term found that the acquiring companies earned positive abnormal returns, which contrasts with findings in developed economics where acquiring firms generally experience negative or no returns from acquisition announcement. In addition of that no studies investigated the impact of medium of exchange in acquisitions on value of listed acquiring companies in both developed and developing economics based on Long-Term Event Study Methodology. But all literature review based on accounting indications from audited published financial statement when evaluating performance of stock price in long - term. Accordingly, we have constructed hypothesis No3 and No4 as follow :

H3: There is no significant impact of acquisitions deals announcement according to financing decisions on realized return of acquiring companies' shares surrounding date of acquisitions announcement.

H4: There is no significant impact of acquisitions deals announcement according to financing decisions on realized return of acquiring companies' shares on long-term.

\section{Sample Selection and Data Collection}

This study data based on acquisitions announced by Egyptian corporates during the period 2005-2011 which is 212 acquisitions deals which is completed at Egyptian stock exchange during that period. According to the objective of the paper which is examining the impact of acquisition deals announcement according to financing decisions on value of listed acquiring companies at Egyptian stock exchange, the study focused on the shareholders' wealth of the acquiring companies which completed the acquisitions and fulfilled the following conditions:

- The acquiring companies had completed the acquisition and acquired the shares of the target companies.

- $\quad$ Stocks of the acquiring companies listed in Egyptian stock exchange. 
- Stocks of the acquiring companies are traded at Egyptian stock exchange both pre-event and post-event in short-term and long-term.

- Acquisitions of minor stakes (that is less $51 \%$ ) have been excluded from the sample.

After applying the selection criteria, the sample is reduced to 31 acquisitions deals completed during the period 2005-2011 listed in Egyptian stock exchange and traded both pre-event and post-event in short-term and long-term. Moreover, the acquiring companies had been owned more than $51 \%$ from equity of the target companies. Table (1) showed the selected acquiring companies details as following:

Table 1. Sample of the acquiring companies

\begin{tabular}{|c|c|c|c|c|c|}
\hline$\underline{\underline{N o}}$ & $\begin{array}{l}\text { Acquiring } \\
\text { companies }\end{array}$ & Target companies & $\begin{array}{l}\text { Percentage of } \\
\text { Acquisitions }\end{array}$ & $\begin{array}{l}\text { Date of } \\
\text { Acquisitions }\end{array}$ & $\begin{array}{l}\text { Method of } \\
\text { financing }\end{array}$ \\
\hline 1 & $\begin{array}{l}\text { Orascom } \\
\text { construction } \\
\text { industries }\end{array}$ & $\begin{array}{l}\text { Egyptian cement } \\
\text { company (EEC) }\end{array}$ & $53.66 \%$ & $15 / 8 / 2005$ & Cash \\
\hline 2 & $\begin{array}{l}\text { Societe Arabe } \\
\text { Internationale } \\
\text { Banque SAIB }\end{array}$ & $\begin{array}{l}\text { Port said national } \\
\text { development bank }\end{array}$ & $99.99 \%$ & $26 / 7 / 2005$ & Cash \\
\hline 3 & $\begin{array}{l}\text { Olympic Group } \\
\text { Financial } \\
\text { Investments } \\
\text { Company }\end{array}$ & Ideal Industries & $93.18 \%$ & $16 / 8 / 2005$ & $\begin{array}{l}\text { Exchange of } \\
\text { Shares }\end{array}$ \\
\hline 4 & Suez Cement & ASEC For Cement & $98.69 \%$ & $25 / 8 / 2005$ & Cash \\
\hline 5 & $\begin{array}{lr}\text { Saudi } & \text { Egyptian } \\
\text { Investment } & \& \\
\text { Finance } & \end{array}$ & Giza Cables & $\begin{array}{l}17 \% \\
\text { controlling }\end{array}$ & $16 / 11 / 2006$ & Cash \\
\hline 6 & Credit Agricole & $\begin{array}{l}\text { Egyptian American } \\
\text { Bank }\end{array}$ & $56.15 \%$ & $18 / 6 / 2006$ & $\begin{array}{l}\text { Exchange of } \\
\text { Shares }\end{array}$ \\
\hline 7 & Telecom Egypt & Vodafone Egypt & $49 \%$ & $19 / 10 / 2006$ & Cash \\
\hline 8 & $\begin{array}{l}\text { Misr Conditioning } \\
\text { (MIRACO) }\end{array}$ & $\begin{array}{l}\text { MIRACO } \\
\text { Development } \\
\text { \&Trading }\end{array}$ & $74 \%$ & $3 / 9 / 2006$ & Cash \\
\hline 9 & El Ezz Steel Rebars & $\begin{array}{l}\text { Alexandria National } \\
\text { Iron \& Steel }\end{array}$ & $50.28 \%$ & $4 / 5 / 2006$ & Mixed \\
\hline 10 & El Ezz Steel Rebars & Ezz Industries & $54.23 \%$ & $29 / 6 / 2006$ & Mixed \\
\hline 11 & Suez Cement & Ready Mix Beton & $52 \%$ & $12 / 10 / 2006$ & Mixed \\
\hline 12 & Suez Cement & $\begin{array}{l}\text { Ready Mix Beton } \\
\text { Egypt }\end{array}$ & $52 \%$ & $12 / 10 / 2006$ & Mixed \\
\hline 13 & Oriental Weavers & Moquette Mac & $53.1 \%$ & $20 / 7 / 2006$ & $\begin{array}{l}\text { Exchange of } \\
\text { Shares }\end{array}$ \\
\hline 14 & Oriental Weavers & $\begin{array}{l}\text { Oriental Weavers U } \\
\text { S A }\end{array}$ & $100 \%$ & $20 / 7 / 2006$ & $\begin{array}{l}\text { Exchange of } \\
\text { Shares }\end{array}$ \\
\hline 15 & Oriental Weavers & Egyptian Fibers & $76.6 \%$ & $20 / 7 / 2006$ & $\begin{array}{l}\text { Exchange of } \\
\text { Shares }\end{array}$ \\
\hline 16 & $\begin{array}{l}\text { Talaat Moustafa } \\
\text { Group Holding }\end{array}$ & $\begin{array}{l}\text { Arab Company for } \\
\text { Projects }\end{array}$ & $99.99 \%$ & $28 / 10 / 2007$ & $\begin{array}{l}\text { Exchange of } \\
\text { Shares }\end{array}$ \\
\hline 17 & $\begin{array}{l}\text { Talaat Moustafa } \\
\text { Group Holding }\end{array}$ & $\begin{array}{l}\text { Alexandria } \\
\text { Company for Real } \\
\text { Estate Investment }\end{array}$ & $98.57 \%$ & 28/10/2007 & $\begin{array}{l}\text { Exchange of } \\
\text { Shares }\end{array}$ \\
\hline
\end{tabular}




\begin{tabular}{|c|c|c|c|c|c|}
\hline 18 & $\begin{array}{l}\text { Talaat Moustafa } \\
\text { Group Holding }\end{array}$ & $\begin{array}{l}\text { San } r \text { Stefano } \\
\text { company for real } \\
\text { estate investment }\end{array}$ & $95.53 \%$ & $28 / 10 / 2007$ & $\begin{array}{l}\text { Exchange of } \\
\text { Shares }\end{array}$ \\
\hline 19 & $\begin{array}{l}\text { Talaat Moustafa } \\
\text { Group Holding }\end{array}$ & $\begin{array}{l}\text { Alexandria Urban } \\
\text { Projects }\end{array}$ & $100 \%$ & $28 / 10 / 2007$ & $\begin{array}{l}\text { Exchange of } \\
\text { Shares }\end{array}$ \\
\hline 20 & $\begin{array}{l}\text { Naeem Holding For } \\
\text { Investment }\end{array}$ & $\begin{array}{l}\text { Naeem Financial } \\
\text { Investment }\end{array}$ & $62 \%$ & $12 / 9 / 2007$ & Cash \\
\hline 21 & $\begin{array}{l}\text { Naeem Holding For } \\
\text { Investment }\end{array}$ & $\begin{array}{l}\text { Naeem Dubai for } \\
\text { shares and bonds }\end{array}$ & $100 \%$ & $12 / 9 / 2007$ & Cash \\
\hline 22 & $\begin{array}{l}\text { Naeem Holding For } \\
\text { Investment }\end{array}$ & $\begin{array}{l}\text { Naeem Financial } \\
\text { Investment }\end{array}$ & $98 \%$ & $30 / 10 / 2008$ & Cash \\
\hline 23 & $\begin{array}{l}\text { Naeem Holding For } \\
\text { Investment }\end{array}$ & $\begin{array}{lr}\text { United } & \text { Capital } \\
\text { Company } & \text { for } \\
\text { Financial } & \\
\text { Investments } & \text { - Dubai }\end{array}$ & $80 \%$ & $30 / 10 / 2008$ & Cash \\
\hline 24 & $\begin{array}{l}\text { Orascom } \\
\text { construction } \\
\text { industries }\end{array}$ & $\begin{array}{l}\text { Egyptian Fertilizers } \\
\text { Company }\end{array}$ & $99.99 \%$ & $21 / 2 / 2008$ & Cash \\
\hline 25 & $\begin{array}{l}\text { Orascom } \\
\text { construction } \\
\text { industries }\end{array}$ & Sorfert Algeria & $50.99 \%$ & $21 / 2 / 2008$ & Cash \\
\hline 26 & $\begin{array}{l}\text { Commercial } \\
\text { International Bank } \\
\text { CIB }\end{array}$ & $\begin{array}{l}\text { C I Capital Holding } \\
\text { Company }\end{array}$ & $99.99 \%$ & $9 / 7 / 2008$ & Cash \\
\hline 27 & $\begin{array}{l}\text { Orascom } \\
\text { Development } \\
\text { Holding }\end{array}$ & $\begin{array}{l}\text { Orascom Hotels and } \\
\text { Development }\end{array}$ & $98.1 \%$ & $21 / 12 / 2009$ & $\begin{array}{l}\text { Exchange of } \\
\text { Shares }\end{array}$ \\
\hline 28 & $\begin{array}{l}\text { Olympic Group } \\
\text { Financial } \\
\text { Investments } \\
\text { Company }\end{array}$ & $\begin{array}{l}\text { Cairo For Feeding } \\
\text { Industrial }\end{array}$ & $98.9 \%$ & $5 / 8 / 2009$ & $\begin{array}{l}\text { Exchange of } \\
\text { Shares }\end{array}$ \\
\hline 29 & $\begin{array}{l}\text { National Bank for } \\
\text { Development }\end{array}$ & $\begin{array}{l}\text { National Cristal \& } \\
\text { Glass Company }\end{array}$ & $88.3 \%$ & $13 / 4 / 2009$ & Cash \\
\hline 30 & $\begin{array}{l}\text { National Bank for } \\
\text { Development }\end{array}$ & $\begin{array}{lr}\text { Cairo } & \text { National } \\
\text { Company } & \text { for } \\
\text { Investment } & \end{array}$ & $64.75 \%$ & $1 / 11 / 2010$ & $\begin{array}{l}\text { Exchange of } \\
\text { Shares }\end{array}$ \\
\hline 31 & $\begin{array}{lr}\text { Orascom } & \text { Telecom } \\
\text { Media } & \text { And } \\
\text { Technology } & \\
\text { Holding } & \end{array}$ & $\begin{array}{l}\text { Dear And Deal } \\
\text { Company }\end{array}$ & $51 \%$ & $31 / 1 / 2012$ & Cash \\
\hline
\end{tabular}


Table 2. showed sources types and sources of data collected related to each study variable:

\begin{tabular}{|c|c|c|}
\hline Variable & The Data & Sources of Data \\
\hline Free risk return rate & $\begin{array}{l}\text { Rate of the return on treasury } \\
\text { bills for period } 91 \text { days. }\end{array}$ & $\begin{array}{l}\text { Website of central bank of } \\
\text { Egypt. }\end{array}$ \\
\hline $\begin{array}{l}\text { Actual daily return rate for } \\
\text { shares of the sample companies } \\
\text { during period of the event. }\end{array}$ & $\begin{array}{l}\text { Daily closing prices for shares } \\
\text { of the sample companies during } \\
\text { period of the event. }\end{array}$ & $\begin{array}{l}\text { Egypt for } \\
\text { Dissemination. }\end{array}$ \\
\hline $\begin{array}{l}\text { Rate of return on market } \\
\text { portfolio. }\end{array}$ & $\begin{array}{l}\text { Value of market index EGX30 } \\
\text { daily during period of the event. }\end{array}$ & $\begin{array}{l}\text { Website of Egypt stock } \\
\text { exchange. }\end{array}$ \\
\hline $\begin{array}{l}\text { Systematic risk for shares of the } \\
\text { sample companies during period } \\
\text { of the event. }\end{array}$ & $\begin{array}{l}\text { Covariance between return of } \\
\text { shares and return of market } \\
\text { portfolio / Variance of market } \\
\text { return. }\end{array}$ & $\begin{array}{l}\text { Egypt for } \\
\text { Dissemination. }\end{array}$ \\
\hline $\begin{array}{l}\text { Behavior of market prices for } \\
\text { shares of the sample companies } \\
\text { during period of the event. }\end{array}$ & Daily closing prices. & $\begin{array}{l}\text { Egypt for } \\
\text { Dissemination. }\end{array}$ \\
\hline $\begin{array}{l}\text { Medium of exchange In } \\
\text { acquisitions }\end{array}$ & -Stock - Mix. & $\begin{array}{l}\text { Published financial statement or } \\
\text { Egypt for Information } \\
\text { Dissemination. }\end{array}$ \\
\hline
\end{tabular}

\section{Hypotheses and Methodology}

This study focused on the shareholders of acquiring companies and methods of payment used to finance acquisition (cash, stock, and mixed) imposing the following testable hypotheses:

H1: There is no significant impact of the acquisitions deals announcement on realized return of acquiring companies' shares surrounding date of acquisitions announcement.

H2: There is no significant impact of acquisitions deals announcement on realized return of acquiring companies' shares on long-term.

H3: There is no significant impact of acquisitions deals announcement according to financing decisions on realized return of acquiring companies' shares surrounding date of acquisitions announcement.

H4: There is no significant impact of acquisitions deals announcement according to financing decisions on realized return of acquiring companies' shares on long-term.

For testing these hypotheses, stock price method has been used based on event study methodology which depends on market model (Wong \& Kui, 2009) that indicated a linear relationship between security returns and returns on a market portfolio. An event study methodology is a statistical technique that estimates the stock price impact of events such as merger, acquisition, earnings announcements and so forth (Rao \& Sreejith, 2014). Also, event study methodology determines the impact in both short and long horizon (Suryanto, 2015).

\section{(1) Short-term Event Study Methodology:}

Short-term event study methodology used for studying and analysis of abnormal return for shares of acquiring companies surrounding date of acquisitions announcement. This methodology based on eight main steps as following (Mario et al, 2012):

- Defining the event date: announcement day which is the day when the stock exchange is informed about the board approval of the acquisition deal. The study refers to announcement day as the day "0".

- Defining the event window: event window considered 40 days $(-20,+20)$ around announcement day.

- Calculation of normal returns: the study used daily closing prices during the event period. This daily prices series is converted into daily return series per share using the formula:

$$
R_{i t}=\frac{\left(P_{i t}-P_{i t-1}\right)+D_{i t}}{P_{i t-1}}
$$

Where: 
$R_{i t}$ is the rate of return on security $\mathrm{i}$ on day $\mathrm{t}, P_{i t}$ is the closing price on security $\mathrm{i}$ on day $\mathrm{t}, P_{i t-1}$ is the closing price of security $\mathrm{i}$ on day $\mathrm{t}-1$ and $D_{i t}$ is the cash dividend of security $\mathrm{i}$ on the ex-dividend day.

- Calculation of expected returns : Expected returns are calculated as:

$$
\mathrm{E}\left(R_{i t}\right)=R_{f}+\beta_{i}\left(R_{m t}-R_{f}\right)
$$

Where:

$\mathrm{E}\left(R_{i t}\right)$ is the expected return of security $\mathrm{i}$ on day $\mathrm{t}, R_{f}$ is the risk free rate of return, $\beta_{i}$ is the systematic risk of security $\mathrm{i}$, and $R_{m t}$ is the rate of return on the market portfolio during day t.

- Calculation of abnormal return:

Abnormal returns are computed as the difference between actual returns and estimated expected returns.

$$
\mathrm{A} R_{i t}=(\text { actual return })_{i t}-(\text { expected return })_{i t} \text {. }
$$

- Calculation of average abnormal return:

The average abnormal return (AAR) across all securities for any individual time period $(t)$ in the estimation period is obtained by aggregating all abnormal returns of firms on day $\mathrm{t}$ divided by $\mathrm{N}$ (the number of firms with return data on day t) as following:

$$
\mathrm{AAR}=\frac{1}{N_{t}} \sum_{i=1}^{N} A R_{i t}
$$

- Calculation of cumulative average abnormal return

In order to examine the cumulative effect of events, the cumulative average abnormal returns (CAAR) are produced: $\operatorname{CAAR}\left(T_{1}, T_{2}\right)=\sum_{t=T 1}^{T 2} A A R_{t}$

Where $T_{1}$ is the first day of an event period in which the $A A R_{t}$ are accumulated and $T_{2}$ is the last day of an event period in which the $A A R_{t}$ are accumulated.

- Determination of the statistical significance of CAAR and CAR

For testing the statistical impact for CAAR and CAR, we used:

- The mean and standard deviation.

- T-test for the differences between two independent groups if the sample more than 30 .

- Mann Whitney test for the differences between two independent groups if the sample less than 30 units.

- $\quad$ EAT for measuring of the impact strong of event.

\section{(2) Long-Term Event Study Methodology:}

For measuring of long-term stokes' performance for acquiring companies, stock price method based on long-term event study methodology has been used. The main reason for using this approach is that the stocks' returns are direct awards for acquiring companies shareholders. There are two methods in financial literature for measuring long-term stocks' returns based on event study methodology:

- The cumulative average abnormal return (CAAR) method.

- Annual buy and hold abnormal returns (ABHAR) method which is preferred financially as for two aspects (Fang\& Minh, 2013): (1) the ability to evaluate long-term stocks' performance for five years periods or more, and (2) it assumes that the investors bought the share at the closing price of each year's first trading day and sold the share at the closing price of each year's last trading day.

This methodology based on four main steps as following (Mohlmann, 2012):

- Defining the event window: the announcement month is event month. Hence, month of announcement defined as month (0).

- Calculating annual buy and hold abnormal returns for each company included in the sample.

ABHAR is to count the difference between the closing price of first trading day of the year and the closing price of the last trading day adjusted by the market portfolio return. Closing prices must be adjusted by stock dividend and stock split events. ABHAR calculate as following:

$$
A B H A R_{i t}=\frac{P_{i t}-P_{i t-1}}{P_{i t-1}}-\frac{M I_{i t}-M I_{i t-1}}{M I_{i t-1}}
$$


Where:

$A B H A R_{i t}$ is the annual buy-and-hold abnormal return in year (t) after i share's Acquisition, $P_{i t}$ is the last trading day closing price of $\mathrm{t}$ year after i share's acquisition, $P_{i t-1}$ is the last trading day closing price of $\mathrm{t}-1$ year after i share's acquisition, $M I_{i t}$ is the last trading day closing market index after i share's acquisition, $M I_{i t-1}$ is the last trading day closing market index of t-1 year after i share's acquisition.

- Calculate of the average annual buy-and-hold abnormal return In the t Year For All Company as following:

$$
A A B H A R_{t}=\frac{1}{\mathrm{n}} \sum_{i=1}^{n} A B H A R_{i t}
$$

Where:

$A A B H A R_{t}$ is the average annual buy-and-hold abnormal return for all companies in year (t), $A B H A R_{i t}$ is the annual buy-and-hold abnormal return for (i) share in year ( $t$ ), and $\mathrm{n}$ is the sample size.

- Determinations of the statistical significance for the total abnormal return for buy - and - hold abnormal returns.

The study used T - Test Statistical as following:

$$
\mathrm{T}-\mathrm{BHAR}=\frac{A A B H A R_{t}}{\sigma A B H A R_{t} \sqrt{n}}
$$

Where:

T-BHAR is the T-statistic for Buy-and-Hold Abnormal Return, $A A B H A R_{t}$ is the Average Annual Buy-and-Hold Abnormal Return for $\mathrm{t}$ year, $\sigma A B H A R_{t}$ is the standard deviation of Abnormal Returns for the sample of $\mathrm{n}$ firms.

\section{Empirical Results and Analysis}

Analysis of data and testing of hypotheses was completed according to short-term event study methodology, long -term event study methodology and statistical methods which were indicated in part four as following:

\subsection{The First Hypothesis Is:}

H1: There is no significant impact of acquisitions deals announcement on realized return of acquiring companies' shares surrounding date of acquisitions announcement.

The null and alternate hypotheses are as following:

- (H0) The null hypothesis is "There is no significant impact of acquisitions deals announcement on realized return of acquiring companies' shares surrounding date of acquisitions announcement".

- (H1) The alternate hypothesis is "There is significant impact of acquisitions deals announcement on realized return of acquiring companies' shares surrounding date of acquisitions announcement".

For testing this hypothesis, short-term event study methodology was used to analyze abnormal returns for acquiring companies surrounding date of acquisitions announcement. The analysis used the event period 20 days pre-event date , 20 days post-event date $(-20,+20)$. Results achieved by this methodology (see table 3 ) revealed that daily average abnormal returns for period of pre-acquisitions announcement date and period of post-acquisitions announcement date as following: 
Table 3. Daily average abnormal returns for pre-acquisition and post-acquisition dates

\begin{tabular}{llllll}
\hline Abnormal Returns & Days & $\begin{array}{l}\text { Abnormal } \\
\text { Returns }\end{array}$ & Days & $\begin{array}{l}\text { Abnormal } \\
\text { Returns }\end{array}$ & Days \\
\hline$(.003)$ & 1 & $(.016)$ & 0 & $(.045)$ & -20 \\
$(.051)$ & 2 & & $(.050)$ & -19 \\
$(.062)$ & 3 & & $(.045)$ & -18 \\
$(.052)$ & 4 & & $(.054)$ & -17 \\
$(.048)$ & 5 & & $(.045)$ & -16 \\
$(.047)$ & 6 & & $(.054)$ & -15 \\
$(.056)$ & 7 & & $(.050)$ & -14 \\
$(.037)$ & 8 & & $(.068)$ & -13 \\
$(.062)$ & 9 & & $(.042)$ & -12 \\
$(.059)$ & 10 & & $(.055)$ & -11 \\
$(.054)$ & 11 & & $(.053)$ & -10 \\
$(.054)$ & 12 & & $(.049)$ & -9 \\
$(.059)$ & 13 & & $(.052)$ & -8 \\
$(.052)$ & 14 & & $(.046)$ & -7 \\
$(.057)$ & 15 & & $(.058)$ & -6 \\
$(.046)$ & 16 & & $(.054)$ & -5 \\
$(.053)$ & 17 & & $(.053)$ & -4 \\
$(.048)$ & 18 & $(.051)$ & -3 \\
$(.049)$ & 19 & $(.043)$ & -2 \\
$(.056)$ & 20 & $(.048)$ & -1 \\
\hline
\end{tabular}

The results achieved by T-test Statistical as following:

\section{T-Test first hypothesis}

Table 4. Group Statistics

\begin{tabular}{llllll}
\hline The event & & $\mathrm{N}$ & Mean & Std. Deviation & Std. Error Mean \\
\hline \multirow{3}{*}{ daily average abnormal returns } & pre- acquisitions & 620 & -.05105 & .052520 & .002109 \\
\cline { 2 - 6 } & post-acquisitions & 651 & -.04922 & .074842 & .002933 \\
\hline
\end{tabular}

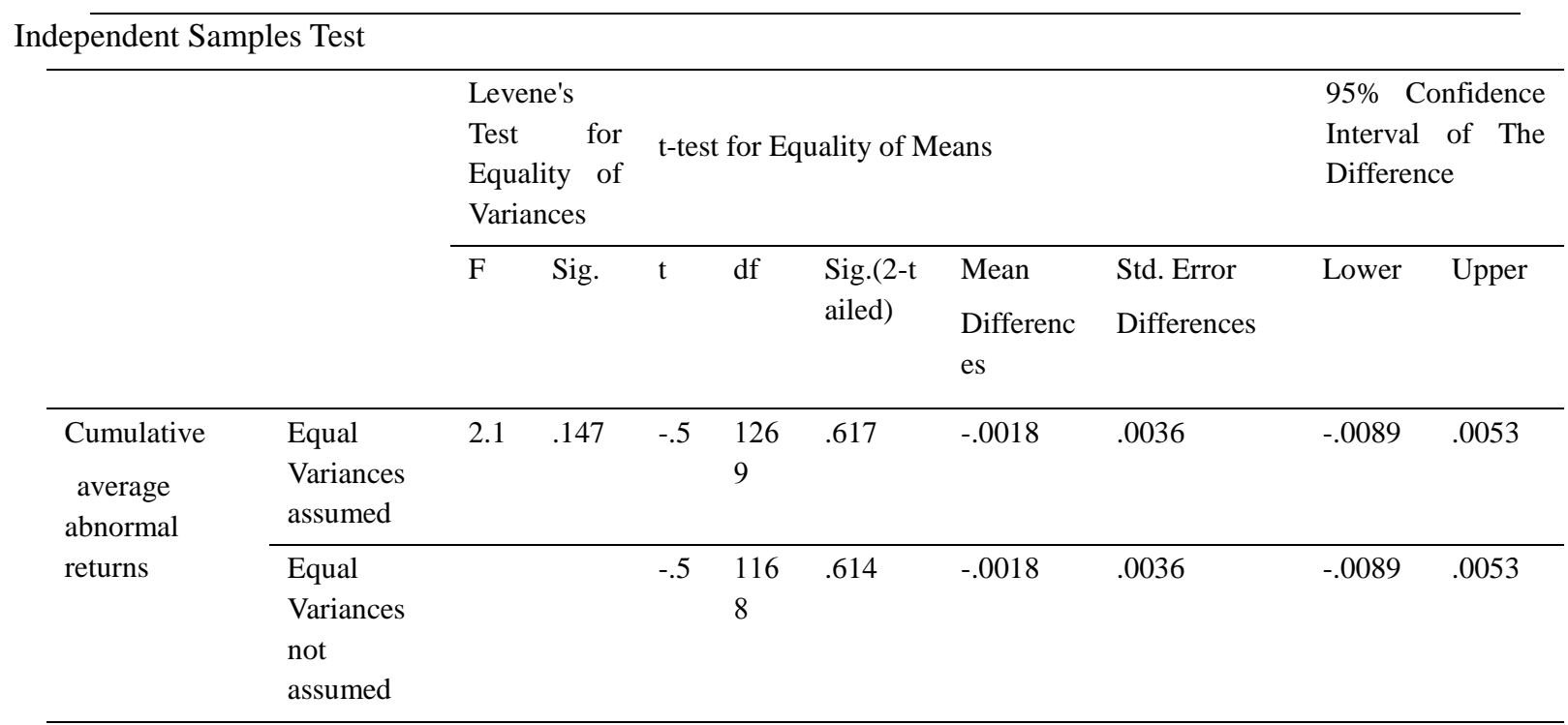


The results of T- test statistical (see table 4) revealed that the number under "Sig "for" Levene's test for equality of variances " is .147 more than .05 , then using the T-value for the "equal variances assumed ". Results under "Sig (2-tailed)" revealed that the "sig" value is .617 (which is greater than .05) referring to accepting the null hypothesis with confidence rate .95 and to reject of the alternate hypothesis. Hence, we can state that there is no significant impact of acquisitions deals announcement on realized return of acquiring companies' shares surrounding date of acquisitions announcement.

\subsection{The Second Hypothesis Is:}

H2: There is no significant impact of acquisitions deals announcement on realized return of acquiring companies' shares in long-term.

The null and alternate hypothesis as following:

- (H0) The null hypothesis is "There is no significant impact of acquisitions deals announcement on realized return of acquiring companies' shares in long-term ".

- (H1) The alternate hypothesis is "There is significant impact of acquisitions deals announcement on realized return of acquiring companies' shares in long-term".

For testing this hypothesis, long-term event study methodology was used to analyze abnormal returns for acquiring companies' post- date of acquisitions announcement in long-term. This methodology based on annual buy - and hold abnormal returns (ABHAR) method for evaluating of acquiring companies ' stock performance in post-acquisitions deals announcement in long-term. Hence, Period of the event consists of five years pre-acquisitions deals announcement and five years post-acquisitions deals announcement (- 5 years, +5 years). Results achieved (see table 5) revealed that the average annual buy-and-hold abnormal returns pre-acquisitions deals month for five years of all the sample companies and the average annual buy - and - hold abnormal returns post-acquisitions deals month for five years of all the sample companies are as following:

Table 5. The Average Annual Buy-and-Hold Abnormal Return for the sample companies pre-event month

\begin{tabular}{llllll}
\hline-1 & -2 & -3 & -4 & -5 & The Years \\
$(.212)$ & $(2.154)$ & $(.192)$ & $(.303)$ & $(.350)$ & AABHAR
\end{tabular}

The Average Annual Buy-and-Hold Abnormal Return for the sample companies post-event month

\begin{tabular}{llllll}
\hline 5 & 4 & 3 & 2 & 1 & The Years \\
-.066 & -.183 & -.077 & -.185 & -.085 & AABHAR
\end{tabular}

The results achieved by T-Test Statistical as following:

T-Test hypothesis 2(31Company)

Table 6. Group Statistics

\begin{tabular}{llllll}
\hline The event & $\mathrm{N}$ & Mean & $\begin{array}{l}\text { Std. } \\
\text { Deviation }\end{array}$ & $\begin{array}{l}\text { Std. Error } \\
\text { Mean }\end{array}$ \\
\hline $\begin{array}{l}\text { Buy } \\
\text { and-Hold }\end{array}$ & pre- Event & 155 & -.64219 & 2.618707 & .210340 \\
\cline { 2 - 6 } & post-Event & 155 & .10602 & .586622 & .047119 \\
\hline
\end{tabular}

Independent Samples Test

\begin{tabular}{|c|c|c|c|c|c|c|c|c|c|c|}
\hline & & \multicolumn{7}{|c|}{ Levene's test } & \multicolumn{2}{|c|}{$95 \% \quad$ Confidence } \\
\hline & & \multicolumn{2}{|c|}{$\begin{array}{l}\text { for Equality } \\
\text { of Variances }\end{array}$} & \multicolumn{3}{|c|}{ t-test for Equality of Means } & & & \multicolumn{2}{|c|}{$\begin{array}{l}\text { Interval of The } \\
\text { Difference }\end{array}$} \\
\hline & & $\mathrm{F}$ & Sig. & $\mathrm{t}$ & df & Sig.(2-tailed) & $\begin{array}{l}\text { Mean } \\
\text { Differences }\end{array}$ & $\begin{array}{l}\text { Std. Error } \\
\text { Differences }\end{array}$ & Lower & Upper \\
\hline \multirow{2}{*}{$\begin{array}{l}\text { Cumulative } \\
\text { average } \\
\text { abnormal } \\
\text { returns }\end{array}$} & $\begin{array}{l}\text { Equal } \\
\text { Variances } \\
\text { assumed }\end{array}$ & 16.3 & .000 & -3.5 & 308 & .001 & -.7482 & .2155 & -1.172 & -.3240 \\
\hline & $\begin{array}{l}\text { Equal } \\
\text { Variances } \\
\text { not } \\
\text { assumed }\end{array}$ & & & -3.5 & 169 & .001 & -.7482 & .2155 & -1.173 & -.3226 \\
\hline
\end{tabular}


The results of T-test (see table 6) revealed that the number under "Sig "for" Levene's test for equality of variances " is .000 (which is less than .05), then using the T-value for the "equal variances not assumed". The results under "sig $(2$ - tailed)" revealed that the "sig" value is .001 (which is less than .05) referring to accepting of the alternate hypothesis with confidence rate .95 and to reject of the null hypothesis. Hence, we can say that there are significant impact of acquisitions deals announcement on realized return of acquiring companies' shares in long-term".

The study used EAT measurement for calculating rate of the impact. The results showed that rate of the impact of acquisitions deals announcement on performance of stocks ' prices for acquiring companies is $67.26 \%$, Based on EAT measurement that rate of the impact is reduced.

\subsection{The Third Hypothesis Is:}

H3: There no significant impact of acquisitions deals announcement according to financing decisions on realized return of acquiring companies' shares surrounding date of acquisitions announcement.

The null and alternate hypothesis as following:

- (H0) The null hypothesis is "There is no significant impact of acquisitions deals announcement according to financing decisions on realized return of acquiring companies' shares surrounding date of acquisitions announcement ".

- (H1) The alternate hypothesis is "There is significant impact of acquisitions deals announcement according to financing decisions on realized return of acquiring companies' shares surrounding date of acquisitions announcement".

For testing this hypothesis, short-term event study methodology used to analyze abnormal returns for acquiring companies stocks according to financing method surrounding date of acquisitions announcement. Event period 20 days pre-event date, 20 days post-event date $(-20,+20)$ is used. We also classified the acquiring companies based on mode of financing to three modes such as Financing with cash, financing with exchange of shares, and mixed financing (see table 7) as following:

Table 7. The acquiring company according to mode of financing

\begin{tabular}{|c|c|c|c|c|}
\hline \multicolumn{5}{|c|}{ Financing with cash } \\
\hline 1 & Acquiring companies & Target companies & $\begin{array}{l}\text { Percentage of } \\
\text { Acquisitions }\end{array}$ & $\begin{array}{l}\text { Date of } \\
\text { Acquisitions }\end{array}$ \\
\hline 1 & Orascom construction industries & Egyptian cement company (EEC) & $53.66 \%$ & $15 / 8 / 2005$ \\
\hline 2 & $\begin{array}{l}\text { Societe Arabe Internationale De } \\
\text { Banque SAIB }\end{array}$ & $\begin{array}{l}\text { Port said national development } \\
\text { bank }\end{array}$ & $99.99 \%$ & $26 / 7 / 2005$ \\
\hline 3 & Suez Cement & ASEC For Cement & $98.69 \%$ & $25 / 8 / 2005$ \\
\hline 4 & $\begin{array}{l}\text { Saudi Egyptian Investment \& } \\
\text { Finance }\end{array}$ & Giza Cables & $\begin{array}{l}17 \% \\
\text { controlling }\end{array}$ & $16 / 11 / 2006$ \\
\hline 5 & Telecom Egypt & Vodafone Egypt & $49 \%$ & $19 / 10 / 2006$ \\
\hline 6 & Misr Conditioning (MIRACO) & MIRACO Development \&Trading & $74 \%$ & $3 / 9 / 2006$ \\
\hline 7 & Naeem Holding For Investment & Naeem Financial Investment & $62 \%$ & $12 / 9 / 2007$ \\
\hline 8 & Naeem Holding For Investment & Naeem Dubai for shares and bonds & $100 \%$ & $12 / 9 / 2007$ \\
\hline 9 & Naeem Holding For Investment & Naeem Financial Investment & $98 \%$ & $30 / 10 / 2008$ \\
\hline 10 & Naeem Holding For Investment & $\begin{array}{l}\text { United Capital Company for } \\
\text { Financial Investments - Dubai }\end{array}$ & $80 \%$ & $30 / 10 / 2008$ \\
\hline 11 & Orascom construction industries & Egyptian Fertilizers Company & $99.99 \%$ & $21 / 2 / 2008$ \\
\hline 12 & Orascom construction industries & Sorfert Algeria & $50.99 \%$ & $21 / 2 / 2008$ \\
\hline 13 & $\begin{array}{l}\text { Commercial International Bank } \\
\text { CIB }\end{array}$ & C I Capital Holding Copmany & $99.99 \%$ & 9/7/2008 \\
\hline 14 & National Bank for Development & National Cristal \& Glass Company & $88.3 \%$ & $13 / 4 / 2009$ \\
\hline 15 & $\begin{array}{l}\text { Orascom Telecom Media And } \\
\text { Technology Holding }\end{array}$ & Dear And Deal Copmany & $51 \%$ & $31 / 1 / 2012$ \\
\hline
\end{tabular}




\begin{tabular}{|c|c|c|c|c|}
\hline \multicolumn{5}{|c|}{ Financing with exchange of shares } \\
\hline & Acquiring companies & Target companies & $\begin{array}{l}\text { Percentage of } \\
\text { Acquisitions }\end{array}$ & $\begin{array}{l}\text { Date of } \\
\text { Acquisitions }\end{array}$ \\
\hline 1 & $\begin{array}{l}\text { Olympic Group } \\
\text { Investments Company }\end{array}$ & Ideal Industries & $93.18 \%$ & $16 / 8 / 2005$ \\
\hline 2 & Credit Agricole & Egyptian American Bank & $56.15 \%$ & $18 / 6 / 2006$ \\
\hline 3 & Oriental Weavers & Moquette Mac & $53.1 \%$ & $20 / 7 / 2006$ \\
\hline 4 & Oriental Weavers & Oriental Weavers U S A & $100 \%$ & $20 / 7 / 2006$ \\
\hline 5 & Oriental Weavers & Egyptian Fibers & $76.6 \%$ & $20 / 7 / 2006$ \\
\hline 6 & Talaat Moustafa Group Holding & Arab Company for Projects & $99.99 \%$ & $28 / 10 / 2007$ \\
\hline 7 & Talaat Moustafa Group Holding & $\begin{array}{l}\text { Alexandria Company for Real } \\
\text { Estate Investment }\end{array}$ & $98.57 \%$ & $28 / 10 / 2007$ \\
\hline 8 & Talaat Moustafa Group Holding & $\begin{array}{l}\text { San Stefano company for real } \\
\text { estate investment }\end{array}$ & $95.53 \%$ & $28 / 10 / 2007$ \\
\hline 9 & Talaat Moustafa Group Holding & Alexandria Urban Projects & $100 \%$ & $28 / 10 / 2007$ \\
\hline 10 & Orascom Development Holding & $\begin{array}{l}\text { Orascom } \\
\text { Development }\end{array}$ & $98.1 \%$ & $21 / 12 / 2009$ \\
\hline 11 & $\begin{array}{l}\text { Olympic Group Financial } \\
\text { Investments Company }\end{array}$ & Cairo For Feeding Industrial & $98.9 \%$ & $5 / 8 / 2009$ \\
\hline 12 & National Bank for Development & $\begin{array}{l}\text { Cairo National Company for } \\
\text { Investment }\end{array}$ & $64.75 \%$ & $1 / 11 / 2010$ \\
\hline
\end{tabular}

\begin{tabular}{lllll}
\hline Mixed financing & & & \\
\hline & Acquiring companies & Target companies & $\begin{array}{l}\text { Percentage of } \\
\text { Acquisitions }\end{array}$ & $\begin{array}{l}\text { Date of } \\
\text { Acquisitions }\end{array}$ \\
\hline 1 & El Ezz Steel Rebars & $\begin{array}{l}\text { Alexandria National Iron \& } \\
\text { Steel }\end{array}$ & $50.28 \%$ & $4 / 5 / 2006$ \\
2 & El Ezz Steel Rebars & Ezz Industries & $54.23 \%$ & $29 / 6 / 2006$ \\
3 & Suez Cement & Ready Mix Beton & $52 \%$ & $12 / 10 / 2006$ \\
4 & Suez Cement & Ready Mix Beton Egypt & $52 \%$ & $12 / 10 / 2006$ \\
\hline
\end{tabular}

The Results achieved by this methodology (see table 8) revealed that daily average abnormal returns for period of pre-acquisitions announcement date and period of post-acquisitions announcement date were as following:

Table 8. daily average abnormal returns for period of pre - acquisitions announcement date and period of post acquisitions announcement date according to mode of financing

\begin{tabular}{lllllllllllll}
\hline \multicolumn{2}{l}{ Financing with cash } & & \multicolumn{9}{c}{ financing with exchange of shares } & \multicolumn{2}{l}{ mixed financing } \\
\hline $\begin{array}{l}\text { Abnormal } \\
\text { Returns }\end{array}$ & Days & $\begin{array}{l}\text { Abnormal } \\
\text { Returns }\end{array}$ & Days & $\begin{array}{l}\text { Abnormal } \\
\text { Returns }\end{array}$ & Days & $\begin{array}{l}\text { Abnormal } \\
\text { Returns }\end{array}$ & Days & $\begin{array}{l}\text { Abnormal } \\
\text { Returns }\end{array}$ & Days & $\begin{array}{l}\text { Abnormal } \\
\text { Returns }\end{array}$ & Days \\
\hline$(.035)$ & 1 & $(.039)$ & -20 & -.045 & 1 & $(.057)$ & -20 & $(.026)$ & 1 & $(.002)$ & -20 \\
$(.042)$ & 2 & $(.040)$ & -19 & $(.085)$ & 2 & $(.081)$ & -19 & $(.018)$ & 2 & $(.007)$ & -19 \\
$(.052)$ & 3 & $(.033)$ & -18 & $(.087)$ & 3 & $(.061)$ & -18 & $(.026)$ & 3 & $(.043)$ & -18 \\
$(.042)$ & 4 & $(.042)$ & -17 & $(.080)$ & 4 & $(.066)$ & -17 & $(.004)$ & 4 & $(.026)$ & -17 \\
$(.048)$ & 5 & $(.031)$ & -16 & $(.064)$ & 5 & $(.067)$ & -16 & -.002 & 5 & $(.028)$ & -16 \\
$(.052)$ & 6 & $(.038)$ & -15 & $(.067)$ & 6 & $(.083)$ & -15 & -.005 & 6 & $(.033)$ & -15 \\
$(.046)$ & 7 & $(.028)$ & -14 & $(.073)$ & 7 & $(.084)$ & -14 & $(.040)$ & 7 & $(.029)$ & -14 \\
\hline
\end{tabular}




\begin{tabular}{|c|c|c|c|c|c|c|c|c|c|c|c|}
\hline$(.017)$ & 8 & $(.072)$ & -13 & $(.074)$ & 8 & $(.073)$ & -13 & $(.003)$ & 8 & (.039) & -13 \\
\hline$(.036)$ & 9 & $(.026)$ & -12 & (.099) & 9 & (.070) & -12 & $(.043)$ & 9 & $(.022)$ & -12 \\
\hline$(.034)$ & 10 & $(.035)$ & -11 & (.100) & 10 & $(.082)$ & -11 & (.025) & 10 & $(.052)$ & -11 \\
\hline (.032) & 11 & $(.048)$ & -10 & $(.075)$ & 11 & $(.077)$ & -10 & $(.048)$ & 11 & $(.002)$ & -10 \\
\hline$(.048)$ & 12 & $(.044)$ & -9 & $(.079)$ & 12 & $(.073)$ & -9 & (.010) & 12 & (.016) & -9 \\
\hline$(.046)$ & 13 & $(.047)$ & -8 & $(.090)$ & 13 & $(.070)$ & -8 & (.028) & 13 & $(.021)$ & -8 \\
\hline$(.036)$ & 14 & (.027) & -7 & (.086) & 14 & $(.075)$ & -7 & (.030) & 14 & (.025) & -7 \\
\hline$(.058)$ & 15 & $(.048)$ & -6 & $(.064)$ & 15 & $(.075)$ & -6 & $(.035)$ & 15 & $(.040)$ & -6 \\
\hline$(.041)$ & 16 & $(.045)$ & -5 & $(.076)$ & 16 & (.077) & -5 & -.022 & 16 & (.017) & -5 \\
\hline (.047) & 17 & $(.046)$ & -4 & $(.080)$ & 17 & $(.072)$ & -4 & 0 & 17 & (.025) & -4 \\
\hline$(.034)$ & 18 & $(.045)$ & -3 & $(.077)$ & 18 & $(.069)$ & -3 & (.010) & 18 & $(.022)$ & -3 \\
\hline (.039) & 19 & (.039) & -2 & $(.075)$ & 19 & $(.070)$ & -2 & (.016) & 19 & $(.014)$ & -2 \\
\hline$(.044)$ & 20 & $(.032)$ & -1 & $(.091)$ & 20 & $(.077)$ & -1 & (.019) & 20 & $(.021)$ & -1 \\
\hline$(, 037)$ & $\mathbf{0}$ & & & (.188) & 0 & & & $(.023)$ & 0 & & \\
\hline
\end{tabular}

The results achieved by T-test according to cash financing method were as following (see table 9):

Table 9. T-test analysis according to method of financing with cash

\section{T-Test hypothesis 3 total}

\section{Group Statistics}

\begin{tabular}{llllll}
\hline The event & & $\mathrm{N}$ & Mean & $\begin{array}{l}\text { Std. } \\
\text { Deviation }\end{array}$ & $\begin{array}{l}\text { Std. Error } \\
\text { Mean }\end{array}$ \\
\hline $\begin{array}{l}\text { Financing } \\
\text { With Cash }\end{array}$ & pre- Event & 300 & -.04026 & .049053 & .002832 \\
\cline { 2 - 6 } & post-Event & 315 & -.04126 & .049033 & .002763 \\
\hline
\end{tabular}

Independent Samples Test

\begin{tabular}{|c|c|}
\hline Levene's test & $95 \% \quad$ Confidence \\
\hline $\begin{array}{l}\text { for Equality t-test for Equality of Means } \\
\text { of Variances }\end{array}$ & $\begin{array}{l}\text { Interval of The } \\
\text { Difference }\end{array}$ \\
\hline
\end{tabular}

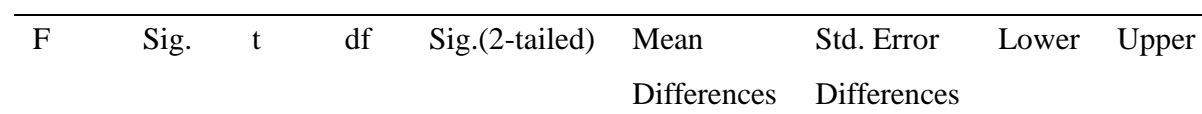

\begin{tabular}{|c|c|c|c|c|c|c|c|c|c|c|}
\hline \multirow[t]{2}{*}{$\begin{array}{l}\text { Financing } \\
\text { With Cash }\end{array}$} & $\begin{array}{l}\text { Equal } \\
\text { Variances } \\
\text { assumed }\end{array}$ & .006 & .937 & .253 & 613 & .800 & .001000 & .003955 & -.0068 & .0088 \\
\hline & $\begin{array}{l}\text { Equal } \\
\text { Variances } \\
\text { not } \\
\text { assumed }\end{array}$ & & & .253 & 612 & .800 & .001000 & .003955 & -.0068 & .0088 \\
\hline
\end{tabular}

The results of T-test revealed that the number under "Sig "for" levene's test for equality of variances " is .937 more than .05 , then using the $\mathrm{T}-$ value for the "equal variances assumed". The results under "sig $(2-$ tailed)" revealed that the "sig" value is .800 (which is more than .05), and it is leading to accept of the null hypothesis with confidence rate .95 and to reject of the alternate hypothesis. Hence, there is no significant impact of acquisitions deals announcement according to cash financing method on realized return of acquiring companies' shares surrounding date of acquisitions announcement.

The results achieved by T-test according to method of financing with exchange of shares as following (see table 10): 
Table 10. T-test Statistical according to method of financing with exchange of shares

Group Statistics

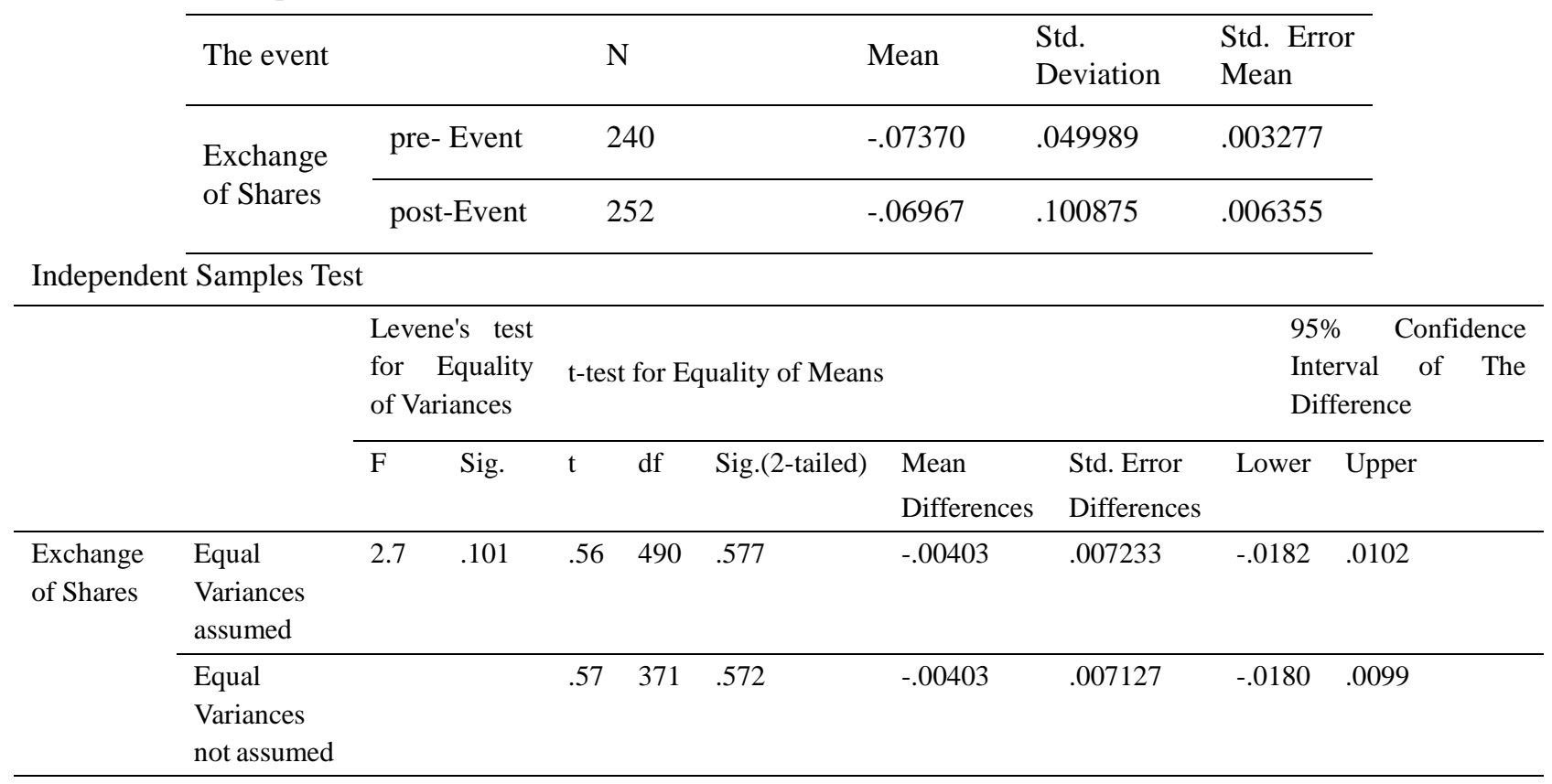

The results of T-test (see table 9) revealed that the number under "Sig" for levene's test for equality of variances " is .558 more than .05 , then using the $\mathrm{T}$ - value for the " equal variances assumed". The results under "sig ( 2 tailed)" revealed that the "sig" value is .577 (which is more than .05), and it is leading to accept of the null hypothesis with confidence rate .95 and to reject of the alternate hypothesis. Hence, there is no significant impact of acquisitions deals announcement according to method of financing with exchange of shares on realized return of acquiring companies' shares surrounding date of acquisitions announcement.

The results achieved by T-Test Statistical according to method of mixed financing as following (see table 11):

Table 11. T-test statistical analysis according to method of mixed financing

\section{Group Statistics}

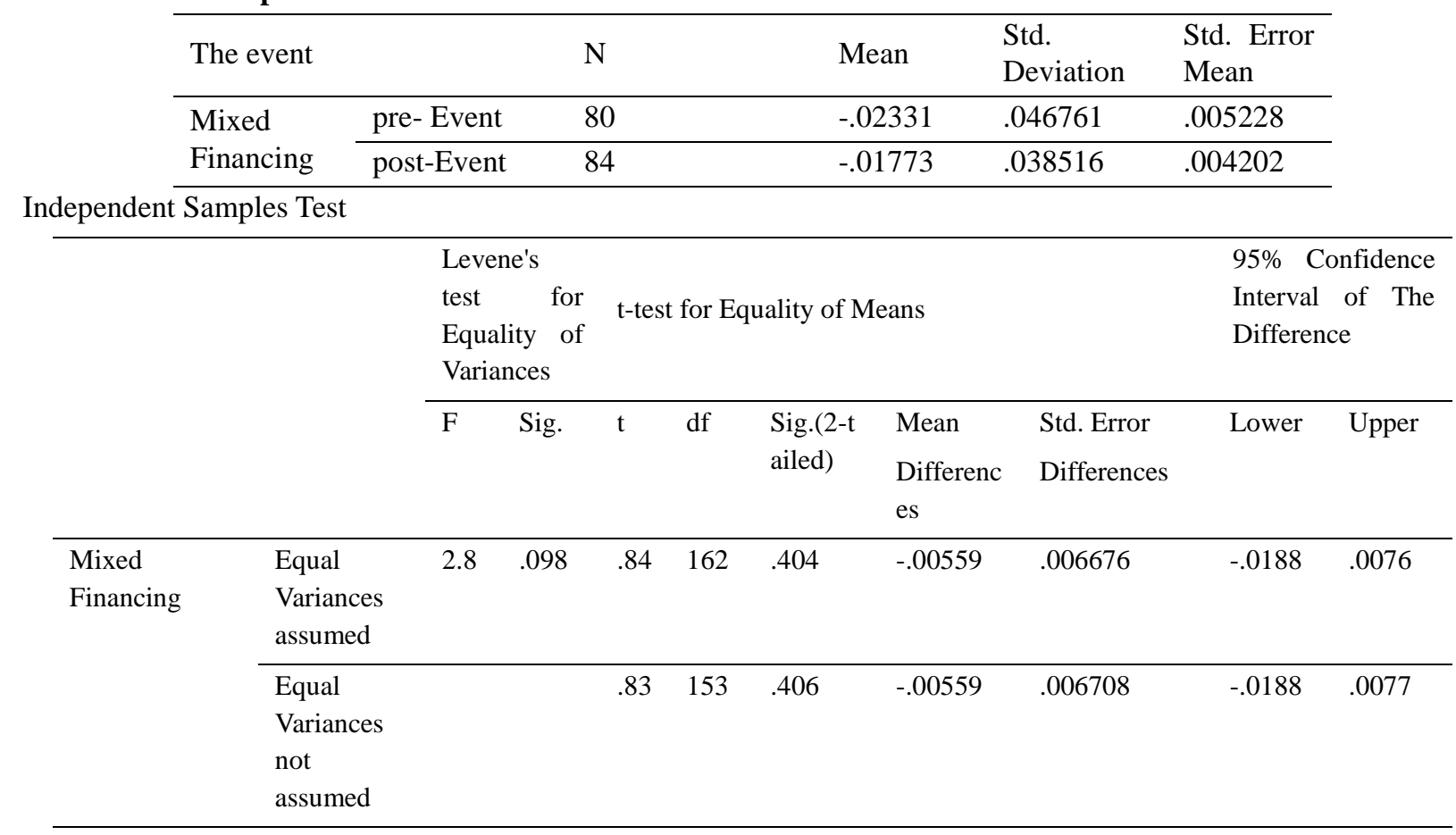


The results of T-Test statistical (see table 9 ) revealed that the number under " Sig " for " levene's test for equality of variances " is .837 more than .05 , then using the $\mathrm{T}$ - value for the " equal variances assumed ". The results under "sig $(2$ - tailed)" revealed that the "sig" value is .404 (which is more than .05), and it is leading to accept of the null hypothesis with confidence rate .95 and to reject of the alternate hypothesis. Hence, there is no significant impact of acquisitions deals announcement according to method of mixed financing on realized return of acquiring companies' $\mathrm{s}$ shares surrounding date of acquisitions announcement.

\subsection{The Fourth Hypothesis Is:}

H4: There no significant impact of acquisitions deals announcement according to financing decisions on realized return of acquiring companies' shares in long-term.

The null and alternate hypothesis as following:

- (H0) The null hypothesis is "There is no significant impact of acquisitions deals announcement according to financing decisions on realized return of acquiring companies' shares in long-term ".

- (H1) The alternate hypothesis is "There is significant impact of acquisitions deals announcement according to financing decisions on realized return of acquiring companies' shares in long-term".

For testing this hypothesis, long-term event study methodology used to analysis of abnormal returns for acquiring companies 'shares in post-date of acquisitions announcement in long-term. This methodology based on annual buy and - hold abnormal returns (ABHAR) method for evaluating of acquiring companies ' stock performance in post-acquisitions deals announcement in long-term. We also classified the acquiring companies based on mode of financing to three modes such as Financing with cash, financing with exchange of shares, and mixed financing (see table 7). Period of the event consists of five years pre-acquisitions deals announcement and five years post-acquisitions deals announcement (- 5 years, +5 years). The Results achieved (see table 12) reveals that the average annual buy-and-hold abnormal returns pre-acquisitions deals announcement month for five years of all the sample companies and the average annual buy - and - hold abnormal returns post-acquisitions deals announcement month for five years of all the sample companies as following:

Table 12.

\begin{tabular}{|c|c|c|c|c|c|c|c|c|c|c|c|}
\hline \multicolumn{4}{|c|}{ Financing with cash } & \multicolumn{2}{|c|}{$\begin{array}{l}\text { financing } \\
\text { shares }\end{array}$} & \multicolumn{2}{|c|}{ exchange of } & \multicolumn{4}{|c|}{ mixed financing } \\
\hline $\begin{array}{l}\text { Abnor } \\
\text { mal }\end{array}$ & $\begin{array}{l}\text { Yea } \\
\text { rs }\end{array}$ & $\begin{array}{l}\text { Abnor } \\
\text { mal }\end{array}$ & $\begin{array}{l}\text { Yea } \\
\text { rs }\end{array}$ & $\begin{array}{l}\text { Abnor } \\
\text { mal }\end{array}$ & $\begin{array}{l}\text { Yea } \\
\text { rs }\end{array}$ & $\begin{array}{l}\text { Abnor } \\
\text { mal }\end{array}$ & $\begin{array}{l}\text { Yea } \\
\text { rs }\end{array}$ & $\begin{array}{l}\text { Abnor } \\
\text { mal }\end{array}$ & $\begin{array}{l}\text { Yea } \\
\text { rs }\end{array}$ & $\begin{array}{l}\text { Abnorm } \\
\text { al }\end{array}$ & $\begin{array}{l}\text { Yea } \\
\text { rs }\end{array}$ \\
\hline $\begin{array}{l}\text { Return } \\
\mathrm{s}\end{array}$ & & Returns & & $\begin{array}{l}\text { Return } \\
\mathrm{s}\end{array}$ & & $\begin{array}{l}\text { Return } \\
\mathrm{s}\end{array}$ & & $\begin{array}{l}\text { Return } \\
\mathrm{s}\end{array}$ & & Returns & \\
\hline-.488 & 1 & $(.295)$ & -5 & $(.296)$ & 1 & $(.522)$ & -5 & $(.283)$ & 1 & $(.038)$ & -5 \\
\hline-.160 & 2 & $(.686)$ & -4 & -.163 & 2 & -.129 & -4 & -.007 & 2 & $(.022)$ & -4 \\
\hline-.143 & 3 & $(.019)$ & -3 & -.078 & 3 & $(.919)$ & -3 & $(.154)$ & 3 & $(1.378)$ & -3 \\
\hline-.225 & 4 & $(1.459)$ & -2 & $(.042)$ & 4 & $(.747)$ & -2 & -.376 & 4 & $(8.984)$ & -2 \\
\hline-.127 & 5 & $(.263)$ & -1 & -.056 & 5 & $(.456)$ & -1 & $(.133)$ & 5 & -.716 & -1 \\
\hline
\end{tabular}

The results achieved by T-Test Statistical according to cash financing method as following (see table 13):

Table 13. T-test statistical analysis according to method of financing with cash

Group Statistics

\begin{tabular}{lccccc}
\hline The event & & $\mathrm{N}$ & Mean & $\begin{array}{l}\text { Std. } \\
\text { Deviation }\end{array}$ & $\begin{array}{l}\text { Std. Error } \\
\text { Mean }\end{array}$ \\
\hline $\begin{array}{l}\text { Financing } \\
\text { With Cash }\end{array}$ & pre- Event & 75 & -.54440 & .049053 & .002832 \\
\cline { 2 - 6 } & post-Event & 75 & .21569 & .049033 & .002763 \\
\hline
\end{tabular}


Independent Samples Test

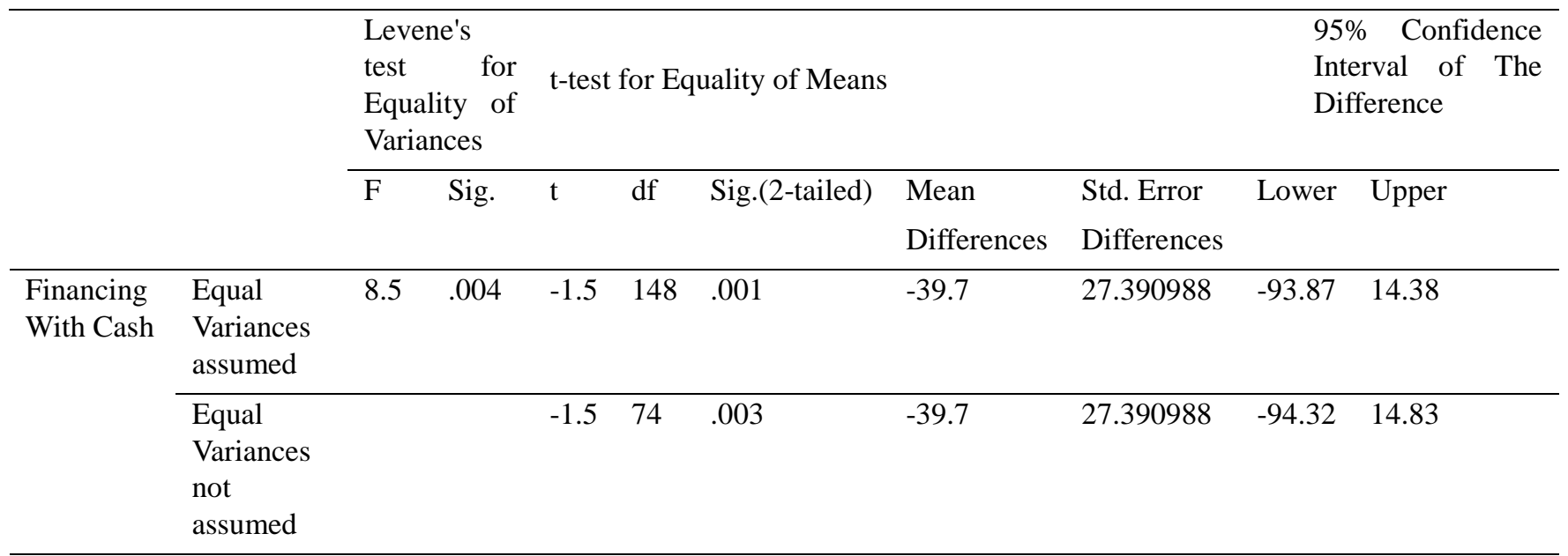

The results of T-Test statistical (see table 13) reveals that the number under "Sig "for" levene's test for equality of variances " is .004 less than .05 , then using the T-value for the "equal variances not assumed ". The results under "sig ( 2 - tailed)" reveals that the "sig" value is .003 (which is less than .05), and it is leading to accept of the alternate hypothesis with confidence rate .95 and to reject of the null hypothesis. Hence, there is significant impact of acquisitions deals announcement on realized return of acquiring companies' shares in long - term according to cash financing method. The study used EAT measurement for calculating rate of the impact. The results show that rate of the impact of acquisitions deals announcement on performance of stocks ' prices for acquiring companies is $16.87 \%$, Based on EAT measurement that rate of the impact is reduce. Hence, there is weak significant impact of acquisitions deals announcement on realized return of acquiring companies' shares in long - term according to cash financing method.

The results achieved by T-Test Statistical according to method of financing with exchange of shares as following (see table 14):

Table 14. T-test statistical analysis according to method of financing with exchange of shares

Group Statistics

\begin{tabular}{lccccc}
\hline The event & $\mathrm{N}$ & Mean & $\begin{array}{l}\text { Std. } \\
\text { Deviation }\end{array}$ & $\begin{array}{l}\text { Std. Error } \\
\text { Mean }\end{array}$ \\
\hline $\begin{array}{l}\text { Financing } \\
\text { With }\end{array}$ & pre- Event & 60 & -.50282 & .929455 & .119992 \\
\cline { 2 - 6 } $\begin{array}{l}\text { Exchange } \\
\text { of Shares }\end{array}$ & post-Event & 60 & -.00883 & .321017 & .041443 \\
\end{tabular}

Independent Samples Test

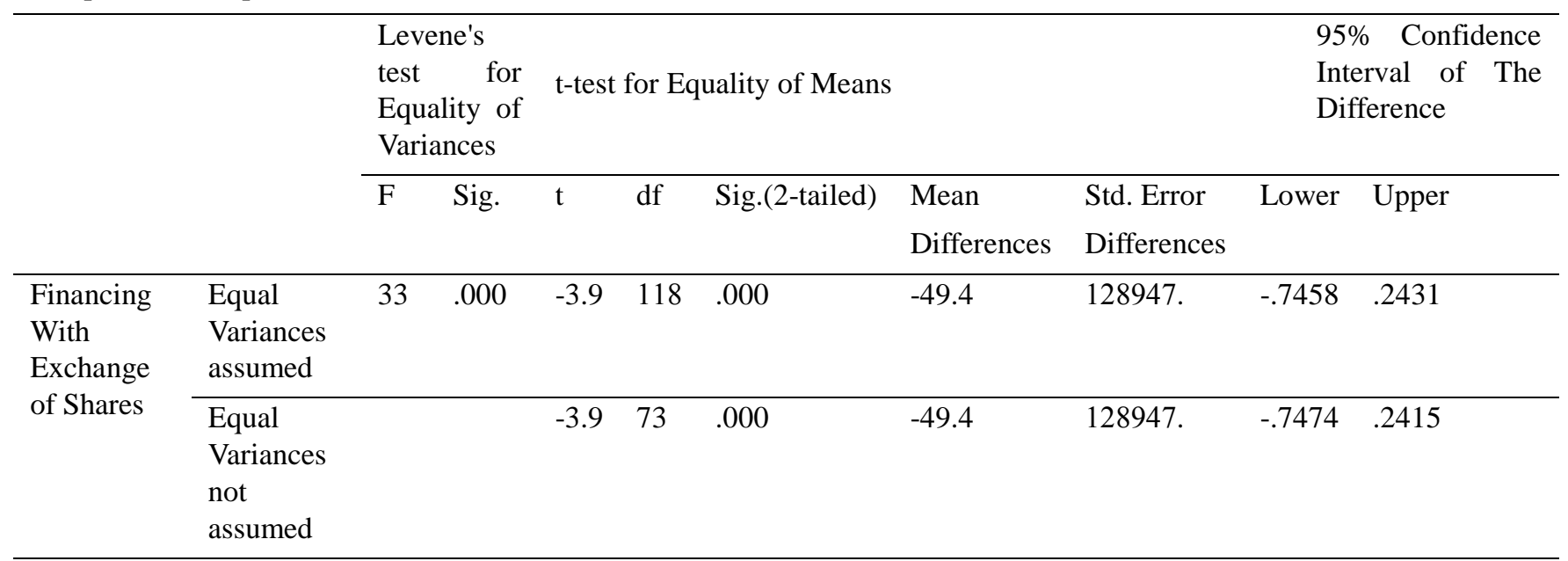


The results of T-Test statistical (see table 13) revealed that the number under "Sig "for" levene's test for equality of variances " is .000 less than .05 , then using the $\mathrm{T}$ - value for the "equal variances not assumed". The results under "sig $(2$ - tailed)" reveals that the "sig" value is .000 (which is less than .05), and it is leading to accept of the alternate hypothesis with confidence rate .95 and to reject of the null hypothesis. Hence, there is significant impact of acquisitions deals announcement on realized return of acquiring companies' shares in long-term according to method of financing with exchange shares. The study used EAT measurement for calculating rate of the impact. The results showed that the rate of the impact of acquisitions deals announcement on performance of stocks ' prices for acquiring companies is $45.63 \%$, Based on EAT measurement that rate of the impact is reduced. Hence, that there is reduction significant impact of acquisitions deals announcement on realized return of acquiring companies' shares in long term according to method of financing with exchange shares.

The results achieved by Mann-Whitney Test Statistical according to method of mixed financing as following (see table 15):

Table 15. Mann-Whitney Test statistical according to method of mixed financing

NPar Tests

Mann-Whitney Test

Ranks

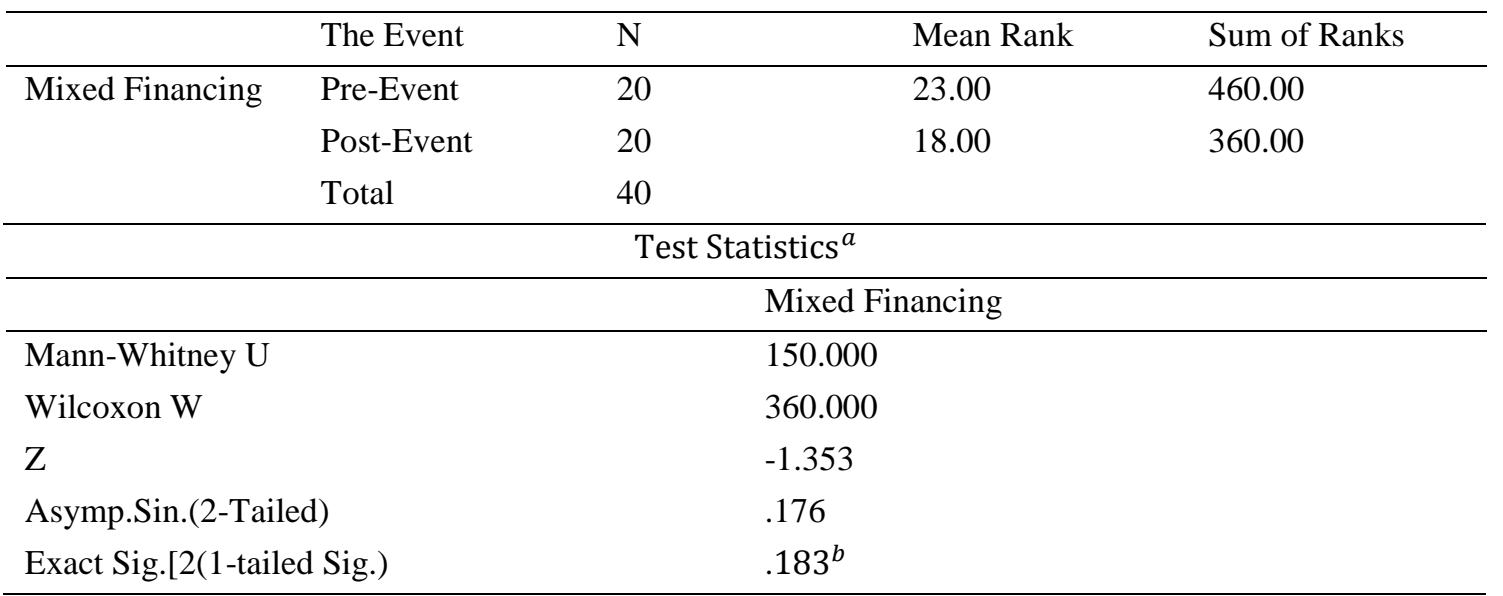

a. Grouping Variable.

b. Not corrected for ties.

NPar Tests

Mann-Whitney Test

\begin{tabular}{llllllll}
\hline Companies & methods & The Event & N & $\begin{array}{l}\text { Mean } \\
\text { Rank }\end{array}$ & $\begin{array}{l}\text { Sum } \\
\text { of } \\
\text { Ranks }\end{array}$ & Z & Sig. \\
& & & & & \\
\hline Ezz Steel & Mixed Financing & Pre-Event & 5 & 7.00 & 35.00 & & \\
& & Post-Event & 5 & 4.00 & 20.00 & & \\
& & Total & 10 & & & -1.6 & .117 \\
Ezz Steel & \multirow{2}{*}{ Mixed Financing } & Pre-Event & 5 & 6.60 & 33.00 & & \\
& & Post-Event & 5 & 4.40 & 22.00 & & \\
& & Total & 10 & & & -1.1 & .251 \\
Suez Cement & Mixed Financing & Pre-Event & 5 & 5.40 & 27.00 & & \\
& & Post-Event & 5 & 5.60 & 28.00 & & \\
& & Total & 10 & & & -0.1 & .917 \\
Suez Cement & Mixed Financing & Pre-Event & 5 & 5.40 & 27.00 & & \\
& & Post-Event & 5 & 5.60 & 28.00 & & \\
& & Total & 10 & & & -0.1 & .917 \\
\hline
\end{tabular}


The results of test which showed in table (15) by Mann-Whitney Test Statistical because volume of the sample is 20 units and it less than 30 units under acquisitions deals which financed by exchange of shares and cash (mixed financing). The results of Mann-Whitney Test reveals that the sig is .176 and it more than .05 , in additional of value of $\mathrm{Z}$ is 1.353 and it less than 1.96 . It means that no differences between pre - event realized average return and postevent realized average return, because that pre-event mean rank is 23 and post-event mean rank is 18 . According to Mann-Whitney Test statistical, there are no statistical differences between mean ranks. It is leading to accept of the null hypothesis with confidence rate .95 and to reject of alternate hypothesis. Hence, there no significant impact of acquisitions deals announcement on realized return of acquiring companies' shares in long-term according to method of mixed financing.

\section{Concluding Observations, Limitations and Future Research Directions}

According to literature review that it recommended for studying the impact of acquisition announcement on acquiring firms' shareholders wealth in short-term and long-term in developing countries, in addition of the impact according to financing decision . Egypt as an emerging market in Africa, hence, the paper applied recommendations of literature on Egyptian acquiring firms' shareholders wealth. This paper differs from previous literature studying acquisitions in two important aspects. First, the study included the impact of acquisition announcement event on Egyptian acquiring firms' shareholders wealth in short-term and long-term in general, and second, the impact of acquisitions on Egyptian acquiring firms' shareholders wealth in short-term and long-term according to method of finance (cash, shares, and mixed).

This paper analyzed the stock performance of Egyptian acquiring companies in both short and long term. This analysis examined whether firms involved in acquisitions deals experienced abnormal return around acquisitions announcement period and in the long-term. Also the study tested if abnormal return on the stock holding of these firms would be affected by types of financing decisions or modes of payment for acquisitions deals in the short-term and long-term.

Short-term and long-term event study methodologies were applied to analyze average abnormal returns and cumulative average abnormal returns for a sample of acquiring companies. Long-term event study methodology was applied according to annually buy - hold abnormal return method (ABHAR). Average abnormal returns and cumulative average abnormal returns were calculated to evaluate the acquirer's return for a sample of 31 acquiring companies listed and traded at Egyptian stock exchange during the period 2005-2014. The Sample was selected from 212 acquiring companies which completed the acquisition during the period. Paired T -test and Mann Whitney and ETA measurement were used to determine whether there was significant difference between the means in pre and post events. The results indicated that acquisitions did not generate cumulative average abnormal returns (CAAR) during the event window of 40 days $(-20,+20)$ for the entire sample, but the acquisitions generated $26.67 \%$ ( statistically significant) cumulative average abnormal returns during long- term event period. The Positive abnormal returns were not observed in the case of acquisitions financed with cash, stock or mix during the event window (short-term) 40 days. But on long-term that the acquisitions financed with cash and stock generated positive abnormal returns but did not observed in the case of acquisition financed with mix method.

\subsection{Policy-Makers Recommendations}

As a results of the empirical research taken on The Impact of Acquisitions Deals Announcement on value of Listed acquiring companies At Egyptian Stock Exchange, we have some suggestions for policy - makers:

- Concentric acquisition generate a higher profitability than conglomeral acquisition according to generate synergies in terms of production, financing, marketing and low risk for the manager's job. Hence, linked acquisition provided higher returns than non linked on long - term.

- According to the paper, financing with cash lead to improvement of acquiring firms' shareholders wealth in long-term than financing with equity and mixed. Hence, we recommend to use method of financing with equity or mixed in case information asymmetry.

\subsection{Recommendations for Further Studies}

This paper is limited as to looking at the short-term and long-term performance of Egyptian acquiring companies. That is why; our recommendations for further studies are as following:

- Studying the impact of acquisitions announcement on value of target companies in emerging and advanced market. 
- Comparison study around the impact of acquisitions announcement on value of acquiring companies between domestic acquisitions and cross-border acquisitions.

- Comparison study around the impact of acquisitions announcement on value of acquiring companies between domestic acquisitions and cross-border acquisitions according to types of financing decisions.

- Measuring market efficiency by using event of acquisitions announcement.

\section{References}

Adekunle, Onaolapo \& Ajala Oladayo. (2013). Post - Merger Performance of Selected Nigerian Deposit Money Banks - An Econometric Perspective. International Journal of Management Sciences and Business Research, 2(8), 49-59.

Ahmad, Melati , Shehzad Khan \& Faisal Khan. ( 2014). Mergers and Acquisitions : A Conceptual Review. International Journal of Accounting and Financial Reporting, 4(2), 520 - 533.

Amir, Muhammad, Rehana Kouser \& Ghulam Mujtaba. ( 2014). Announcement and The Abnormal Stock Return For The Event Firms : Evidence From Pakistan. Pakistan Journal of Social, 34(1), 255-272.

Asauten, Anderibom, Obute Christopher O. (2015). The Effects of Mergers and Acquisitions on The Performance of Commercial Banks of Nigeria: Evidenced from United Bank for Africa (U B A) Plc. International Journal of Education and Research, 3(4), 93-112.

Azhagaiah, Ramachandran \& Thangavelu Sathishkumar. (Summer 2014). Impact of Merger and Acquisition on Operating Performance : Evidence from Manufacturing Firms In India. Managing Global Transition, 12(2), 121-139.

Bouzgarrou , Houssam. (2014). Financing Decision in Acquisition: The Role of Family Control. Procedia Economic and Finance, (13), 3-13. http://dx.doi.org/10.1016/S2212-5671(14)00426-2

Chemmanur, Thomas J. , Imants Paeglis \& Karen Simonyan. (2009). The Medium Of Exchange In Acquisitions : Does The Private Information of Both Acquirer and Target Matter? Journal Of Corporate Finance, 8(4), 1-20. http://dx.doi.org/10.1016/j.jcorpfin.2009.08.004

Domingues, Mario , T.Diana L. Van Aduard De Macedo- Soares, Marcelo Cabus \& Antonio Carlos. (Apr- June 2012). Assessment Of Market Efficiency in Argentina, Brazil and Chile: An Event Study of Mergers and Acquisitions. Brazilian Administration $\quad$ Review, 229-245. http://dx.doi.org/10.1590/S1807-76922012000200007

Fang , Yue \& Minh Huong. (2013). Short-Run and Long-Run Performance of IPOs: Evidence From Taiwan Stock Market. Journal of Finance and Accounting, 1(2), 34-35.

Gaur, Ajai S., Shavin Malhotra \& Pengcheng Zhu. (January 2014). Acquisition Announcements Increase Stock Market Valuations Of Acquiring Firms Rivals In China. International Association for Chinese Management Research, 1-3.

Gersdorff , Nick and Frank Bacon. (2010). U.S. Merger and Acquisitions: A Test of Market Efficiency. Journal of Finance and Accountancy, 1-9.

Jafari , Jamshid \& Tahereh. (2014). The Effect Of Financing Methods On The Profitability Level Of Food Industry Companies Quoted In Tehran Stock Exchange. International Journal Of Academic Research In Accounting, Financing And Management Sciences, 4(3), 36-40 .

Javed , Amir, Benish Javed, Asid Majeed \& Adnan Shaukat. (2013). Impact of Merger and Acquisition on Operating Performance and Shareholder Wealth iPakistan Banking Sector. Interdisciplinary Journal of Contemporary Research in Business, 5(6), 385-391.

Joshua , Okpanachi. (May 2011). Comparative Analysis of The Impact of Mergers and Acquisitions on Financial Efficiency of Banks in Nigeria. Journal of Accounting and Taxation, 3(1), 1-7.

Junappa , Mallikar \& Panduranga Nayak. (July - September 2013). A study Of Wealth Effects of Takeover Announcements in India On Target Company Shareholders. VIKALPA, 38(3), 23-51.

Kalinowska , Aleksandra \& Pawel Mielearz. (2014). Methods Of Payment In M\&A Transactions and The Operational Performance Of Acquirers. Finance, Rynki Finansowe , Ubezpieczenia, (67), 739-746. http://dx.doi.org/10.2139/ssrn.2419742 
Karampatsas, Nikolaos, Dimitris Petmezas \& Nickolaos G. Travlos. (2012). Credit Ratings And The Choice Of Payment Method In Mergers And Acquisitions. Working Papers (University Of Surrey - U K), 27-28.

Kashiramka , Smita \& N.V. Muralidhar Rao. (2013). Shareholders Wealth Effects Of Mergers \& Acquisitions In Different Deal Activity Period In India. European Journal Of Business and Management, 5(4), 116-129.

Khaddafi , Muammar \& Mohd Heikal. (2014). Financial Performance Analysis Using Economic Value Added In Consumption Industry In Indonesia Stock Exchange. American International Journal Of Social Science, 3(4), 219-226.

Knapp, M. , Gart. A. \& Chaudhry. M. (2006). The Impact of Mean Reversion of Bank Profitability on Post Merger Performance in The Banking Industry. Journal of Banking, 30, 3503-3517. http://dx.doi.org/10.1016/j.jbankfin.2006.01.005

Kohli , Reena \& Bikram Jit. (2012). Analyzing Determinants Of Value Creation In Domestic And Border Acquisition In India. International Business Review, 21, 998-1016. http://dx.doi.org/10.1016/j.ibusrev.2011.11.006

Kumar, Muneesh, Shalini Kumar \& Florent Deisting. (2013). Wealth Effects of Bank Mergers In India : A study of Impact On Share Price, Volatility and Liquidity. Banks and Banks System, 8(1), 127-133.

Kumar , Sanjeev \& Sambit Mishra. (April - June 2013). On Overview of Merger and Acquisition. Journal of Indian Research, 1(2), 95- 102.

Liargovas , Panagiotis \& Spyridon Repousis. (2011). The Impact Of Mergers and Acquisitions on The Performance of the Greek Banking Sector: An Event Study Approach. International Journal of Economics and Finance, 3(2), 89-100. http://dx.doi.org/10.5539/ijef.v3n2p89

Liu , Qing \& Larry D. Qiu. (2013). Characteristics Of Acquirers And Targets In Domestic And Cross-Border Mergers And Acquisitions. Review Of Development Economics, 17(3), 474-493. http://dx.doi.org/10.1111/rode.12044

Liu , Yan. (2009). A Comparative Study of IPO Performance and Long - Term Return : Evidence From A+H Listing Companies. Journal Of MacauUniversity Of Science and Technology, 3(1), 75-86.

Mohlmann B.W.A. (July 2012). Hostile Takeovers: The Long Term Effect On Shareholder Value Of Acquiring Companies. Unpublished Master Thesis, Erasmus University Rotterdam, Erasmus School Of Economics, 45-46.

Ma , Jianyu , Jose A.Pagan \& Yun Chu. (2009). Abnormal Returns to Mergers and Acquisitions in Ten Asian Stock Markets. International Journal of Business, 14(3), 235- 250.

Nandy , Dibyendu \& Pankaj Baag. (March 2009). Mergers and Acquisitions. Vidyasagar University Journal of Commerce, 14, $55-70$.

Naserbakht, Mohammad. (2013). Stock Price Behavior of Acquirers and Targets Due to M\&A Announcement in USA Banking. Iranian Economic Review, 17(1), 105-114.

Ramdas , Rajani \& Jyothi Kumar. (2014). Effect of Corporate Restructuring on Shareholders Value In The Information Technology Sector. International Review of Research in Emerging Markets and The Global Economy, 1(1), 33-39.

Rani , Neelam , Surendra S. Yady \& P.K.Jain. (2014). Impact Of Domestic And Cross-Border Acquisition On Acquirer Shareholders' Wealth: Empirical Evidence From Indian Corporate. International Journal Of Business And Management, 9(3), 88-110. http://dx.doi.org/10.5539/ijbm.v9n3p88

Rao , S.V.D. Nageswara \& Sreejith. U. (2014). Event Study Methodology : A Critical Review. The Macrotheme Review Amultidisciplinary Journal Of Global Macro Trends, 3(1), 40-53.

Saikevicius, Darius. (2013). Mergers and Acquisitions : Revisiting the Issue of Value Creation in the New Member States of European Union. ACRN Journal of Entrepreneurship Perspectives, 2(1), 1-13.

Sehgal , Sanjay , Siddhartha Banerjee \& Florent Deisting. (2012). The Impact of M\&A Announcement and Financial Strategy on Stock Returns: Evidence From BRICKS Markets. International Journal of Economics and Finance, 4(11), 76-90. http://dx.doi.org/10.5539/ijef.v4n11p76

Selcuk, E. Akben , A. Altiok Yilmaz. (2011). The Impact of Mergers and Acquisitions on Acquirer Performance: Evidence from Turkey. Business and Economics Journal, 3(1), 1-7.

Saikevicius , Darius. (2013). Mergers and Acquisitions : Revisiting the Issue of Value Creation in the New Member States of European Union. ACRN Journal of Entrepreneurship Perspectives, 2(1), 1-13. 
Samitas, Aristeidis \& Dimitris F. Rienourgio. (2007). Impact Of Mergers And Acquisition On Stock Returns Of Tramp Shipping Firms. Int.J. Financial Services Management, 2(4), 327- 343. http://dx.doi.org/10.1504/IJFSM.2007.016288

Santhiyavalli G. \& Abirami K. (September 2014). Impact of Merger on Firms Performance - A Case Study on Select Banks. Indian Journal of Applied Research, 4(9), 566-570.

Schoenberg, Richard. (2006). Measuring The Performance of Corporate Acquisitions :An Empirical Comparison of Alternative Metrics. British Journal of Management, 17(4), 361-370. http://dx.doi.org/10.1111/j.1467-8551.2006.00488.x

Sehgal , Sanjay, Siddhartha Banerjee \& Florent Deisting. (2012). The Impact of M\&A Announcement and Financial Strategy on Stock Returns: Evidence From BRICKS Markets. International Journal of Economics and Finance, 4(11), 76-90. http://dx.doi.org/10.5539/ijef.v4n11p76

Selcuk , E. Akben , A. Altiok Yilmaz. (2011). The Impact of Mergers and Acquisitions on Acquirer Performance: Evidence from Turkey. Business and Economics Journal, 3(1), 1-7.

Smit CJB , Mjd Ward. (2007). Acquisition on The Share Price and Operating Financial Performance of Acquiring Companies Listed on The JSE. Investment Analysis Journal, (65), 5-14.

Sowunmi , F. A. , O.c. Omigie , L.O. Aikabeli \& M.A. Salako. (2014). Conceptual Approach To Effect Of Information Asymmetry On Auction And Bidding. Asian Journal Of Business Management, 6(2), 76-84.

Stunda , Ronald. (September 2014). The Market Impact Of Mergers And Acquisitions On Acquiring Firms In The U.S.. Journal Of Accounting And Taxation, 6(2), 30-37.

Suryanto. (January 2015). Analysis Of Abnormal Return Before And After The Announcement Of Investment Grade Indonesia. International Journal Of Business And Management Review, 3(1), 11-23.

Suryanto. (January 2015). Analysis Of Abnormal Return Before And After The Announcement Of Investment Grade Indonesia. International Journal Of Business And Management Review, 3(1), 11-23.

Tabtieng, Naratip. (2013). Motivations For Share Repurchase Programs And The Effect Of Share Price On Managerial Decisions To End Share Repurchase Programs In Thailand. International Journal Of Business And Social Science, 4(10), 261.

Terzi , Silvia , Andrea Pierini. (2015). Data Envelopment Analysis (D E A) Assessment Of Composite Indicators Of Infrastructure Endowment. Rivista Di Statistica Ufficiale, (1), 5-18.

Thagunna , Karan S. , Shashank Poudel. (2013). Measuring Bank Performance Of Nepali Banks: A Data Envelopment Analysis (D E A) Perspective. International Journal Of Economics And Financial Issues, 3(1), 54-65.

Torrez, Jimmy , Mohammad Al-Jafari \& Ahmad H Juma'h. (2006). Corporate Valuation : A Literature Review. Revista Empresarial Inter Metro l Iner Metro Business Journal, 2(2), 39-58.

Tsai , Eric. (February 2008). Methods of Payments and Cross-Border Acquiring Firm Valuation. Journal of International Management Studies, 89-97.

Vancea, Mariana. (2008). Challenges and Stakes of The Post - Acquisitions Integration Process. Annals University Series Economics, 13(1), 167-180.

Von, Nick \& Frank Bacon. (2010). U.S. Mergers And Acquisitions: A Test of Market Efficiency. Journal Of Finance And Accountancy, 1-8.

Wong, Anson \& Kui Yin Cheung. (2009). The Effects Of Merger and Acquisition on The securities Prices of Bidding Firms and Target Firms in Asia. International Journal of Economics and Finance, 1(2), 274-283. http://dx.doi.org/10.5539/ijef.v1n2p274

Wright, Greg, Simone Brumton \& Devin Wagner. (2012). Growing Your Business Through Acquisition. International Business Report For Grant Thornton, 1-4. 